\title{
Селекция твердой пшеницы в Италии
}

\author{
О.А. Ляпунова 중 \\ Федеральный исследовательский центр Всероссийский институт генетических ресурсов растений имени Н.И. Вавилова (ВИР), 190000, Россия, \\ г. Санкт-Петербург, ул. Большая Морская, д. 42, 44
}

(C) Автор, 2019

四o.liapounova@vir.nw.ru
Аннотация. Твердая пшеница для Италии - основная зерновая культура. Италия - самый крупный производитель этой культуры в ЕС и первая страна в мире по объему потребления макаронных изделий, которые изготавливают строго из сортов высококачественной твердой пшеницы. Статья посвящена более чем вековой селекции твердой пшеницы в Италии. Подвижническая деятельность первых сельскохозяйственных генетиков, начиная с Назарено Стрампелли, Уго Де Киллиса, Франческо Д'Амато, их коллег и продолжателей, была насыщена драматическими коллизиями и превосходными достижениями, позволившими стране стать самодостаточной в производстве сначала мягкой, затем и твердой пшеницы. Мы также знакомим читателя с основными направлениями селекции твердой пшеницы, обусловленными необходимостью улучшения таких признаков, как скороспелость, устойчивость к полеганию, устойчивость к болезням и вредителям, засухоустойчивость, качество. Сегодня задача науки - помочь ускорить селекционный процесс с использованием новых современных подходов, что решается во всех исследовательских центрах и крупных корпорациях страны. Пример достижений этих исследований - новые сорта, отвечающие вызовам тенденций изменения условий выращивания и повышению требований производителей. В первую очередь нам хотелось более подробно и последовательно познакомить отечественных селекционеров с богатой историей и достижениями селекции твердой пшеницы в Италии.

Ключевые слова: пшеница твердая; история селекции; направления селекции; старый местный сорт; селекционный сорт.

Благодарности. Работа выполнена в рамках государственного задания ВИР № 0662-2019-0006 «Поиск, поддержание жизнеспособности и раскрытие потенциала наследственной изменчивости мировой коллекции зерновых и крупяных культур ВИР для развития оптимизированного генбанка и рационального использования в селекции и растениеводстве».

\section{Durum wheat breeding in Italy}

\section{Olga A. Lyapunova $\otimes$}

Federal Research Center the N.I. Vavilov All-Russian Institute of Plant Genetic Resources (VIR), 42, 44 Bolshaya Morskaya Str., St. Petersburg, 190000, Russia

(C) Autor, 2019

@o.liapounova@vir.nw.ru
Abstract. Durum wheat is the main cereal crop in Italy. Italy is its largest producer in the EU and the leading country in the world in terms of consumption of pasta, which is made strictly from high-quality durum wheat varieties. The article considers the selection of durum wheat in Italy, which has more than a century of history. The ascetic activity of the first agricultural geneticists, beginning from Nazareno Strampelli, Ugo De Cillis, Francesco D'Amato, their colleagues and successors, was full of dramatic conflicts and excellent achievements that allowed the country to become self-sufficient in the production of bread and durum wheat. We also provide an introduction into the main trends in the breeding of durum wheat to improve such features as early maturity, resistance to lodging, resistance to diseases and pests, drought tolerance and quality. The current task of science is to intensify the breeding process using modern approaches, and it is being solved in all research centers and large corporations of the country. An example of the achievements of these studies is new varieties that meet the challenging trends in growing conditions and 
increasing requirements of producers. First of all, we would like to outline the rich history and achievements of durum wheat breeding in Italy for domestic breeders in a detailed and consistent way.

Key words: durum wheat; breeding history; breeding trends; traditional variety; selection variety.

\section{Введение}

Твердая пшеница (Triticum durum Desf.) является одной из основных культур в Италии, что обусловлено большим объемом потребления макаронных изделий, которые изготавливают строго из сортов твердой пшеницы. В Италии и некоторых других странах для любых макаронных изделий используется термин «паста». На итальянском языке слово «паста» означает «тесто», а слово «макароны» - разновидность пасты: тонкие и широкие трубочки сухого теста разной длины.

Посевные площади твердой пшеницы составляют 1.3 млн га, объем производства оценивается в 4.5 млн т. На долю твердой пшеницы приходится 20 \% производства зерновых в стране. В большей степени durum выращивают в самых южных частях полуострова и на островах, причем на области Апулия (Puglia) и Сицилия (Sicilia) приходится около 50 \% площади durum.

Италия является ведущей страной-производителем твердой пшеницы: более 4 млн т в год (США - 2 млн т, Турция - 1.3 млн т и Бразилия и Россия - 1.2 и 1.1 млн т соответственно) (Fazio, 2017). Более $50 \%$ обработанного зерна durum уходит на внутренний рынок пасты и около $50 \%$ - на экспортный рынок. Твердую пшеницу экспортируют в Тунис (84 \%), Францию и Турцию (по 4.8 \%), Грецию (1.3\%), Бельгию (1.2\%) и менее 1 \% - в Германию, Швейцарию и Великобританию (ОЕС, 2017).

По данным Международного совета по зерну (International Grains Council, IGC), в 2017-2018 гг. мировое потребление твердой пшеницы достигло 39.1 млн т, в том числе 2.8 млн т пошло на корм (Boyacioglu, 2017). Италия является страной с самым высоким потреблением макарон на душу населения в мире. По данным Национальной конфедерации фермеров Италии (Coldiretti) и Потребительской кооперации «Кооп-Италия» (Соор), итальянцы съедают в год более 25 кг макарон на одного человека и, в целом, примерно 1.5 млн т пасты. Для удовлетворения потребностей и компенсации экспорта макаронных изделий необходим импорт твердой пшеницы высокого качества. Экспортерами являются Канада (30\%), США (10\%), Австралия и Франция (по $13 \%)$, Казахстан (11\%), Россия (3.4\%), Греция (2.8\%), Испания (2.4\%), Венгрия (1.8\%) Иран (1.3\%), Австрия (1.1\%), затем со значением менее $1 \%$ в порядке убывания следуют Словакия, Германия, Польша, Хорватия, Греция, Турция, Болгария, Румыния и Украина (ОЕС, 2017).

Импорт твердой пшеницы в Италию связан не только с недостатком объема собственного производства, но и с потребностью в высококачественной durum. Италия - первый мировой производитель пасты из твердой пшеницы. Однако качество получаемого урожая для итальянского рынка недостаточно высоко, и низка однородность партии зерна, что обязывает главных производителей пасты импортировать зерно из-за границы. Поэтому Италия импортирует 20 \% потребляемой твердой пшеницы, половина которой прибывает из Канады и США. Только эти страны могут поставить зерно, которое отвечает высоким требованиям к качеству сырья для пасты в Италии.
Канада имеет завидную международную репутацию как надежный поставщик высококачественной пшеницы. Сорта канадского западного янтарного дурума (Canada Western Amber Durum, (WAD) известны своим превосходным желтым цветом, высоким содержанием белка и большим выходом семолины - важными факторами производства пасты и кус-куса высочайшего качества, в то время как высокое содержание глютена обеспечивает хорошие кулинарные характеристики, а повышенное содержание каратиноидов - ярко-желтый цвет. Стремясь удовлетворить спрос Италии на высококачественную, высокой силы клейковины твердую пшеницу, канадские компании приобрели права испытывать, выращивать и продавать сорта durum, происходящие из пустыни. Эти сорта имеют более высокий уровень клейковины и могут помочь Канаде стать более конкурентоспособной на итальянском рынке durum (Italy..., 2003). В США, в Аризоне и Южной Калифорнии, по контрактам с ведущими итальянскими производителями макарон (Barilla, De Cecco и др.) выращивают так называемую пустынную твердую пшеницу. Сельхозпроизводители из этих штатов планируют посевы пшеницы во многом в соответствии с требованиями итальянских изготовителей.

В свою очередь Италия разрабатывает и осуществляет различные протекционистские правила и программы по улучшению качества итальянской durum, что может уменьшить спрос на высококачественную канадскую и американскую твердую пшеницу. В этом контексте рассматриваются научные достижения итальянских селекционеров, направленные на увеличение производства и улучшение качества твердой пшеницы с использованием богатого запаса генетического разнообразия, существующего в районе Средиземноморья, а также зародышевой плазмы, привнесенной из отдаленных географических районов.

\section{История селекции пшеницы в Италии. Назарено Стрампелли - родоначальник современной сельскохозяйственной} генетики

История селекции пшеницы в Италии начинается с Назарено Стрампелли (Nazareno Strampelli) (рис. 1). Он родился 29 мая 1866 г. в Криспьеро (Crispiero), части муниципалитета Кастельраймондо (Castelraimondo), в провинции Мачерата (Macerata) региона Марке (Marke) и получил высшее образование в области сельского хозяйства в Пизанском университете. В начале 1900-х гг., когда менделевские законы о наследовании все еще оставались неизвестными, Н. Стрампелли начал изучать пшеницу с целью улучшения качества и продуктивности. К этому его побудило то, что в начале XX в. Италия почти полностью зависела от импорта пшеницы. Н. Стрампелли хотел обеспечить Италию собственной пшеницей. Его метод, полностью инновационный на тот момент, основывался на следующих положениях: 1) внутривидовая гибридизация генетически отдаленных сортов пшеницы, а позже межродовые скрещивания с участием Aegilops, Secale и Agropyron; 


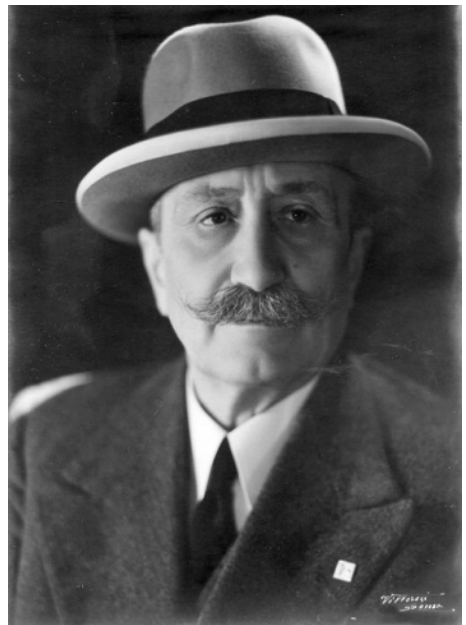

Рис. 1. Назарено Стрампелли (1866-1942) (источник: Bressanini D., 2010).

Fig. 1. Nazareno Strampelli (1866-1942) (a source: Bressanini D., 2010).

2) из растений, полученных в результате скрещивания, были отобраны и размножены особи с наиболее интересными признаками; 3) полученные таким образом константные линии были переданы фитотехническим станциям, которые располагались в 10 местах Италии и предназначались для испытания в разных экологических условиях. Испытания не ограничивались только продуктивностью, а распространялись на стабильность производства, скороспелость, устойчивость к полеганию и к биотическим и абиотическим стрессам, на повышение качества зерна.

Метод Стрампелли был впервые внедрен в 1901 г. В 1903 г. Н. Стрампелли стал педагогом на кафедре сельского хозяйства в Риети. Его внимание привлек местный сорт мягкой пшеницы Rieti, который, выращиваясь с незапамятных времен в долине с холодной зимой, жарким и влажным летом, в среде, очень благоприятной для развития ржавчины, улучшал свои свойства и становился очень устойчивым к стрессам. Его генетические характеристики оставались неизменными на протяжении века, и Н. Стрампелли считал, что отбор в его поколениях был бесполезен. Желая получить новые свойства, Н. Стрампелли начал собирать местные сорта из разных уголков земного шара, чтобы попытаться ввести новые признаки в Rieti через скрещивания (Bressanini, 2010). В 1904 г. он начал разрабатывать программу гибридизации пшеницы на основе менделевских законов, с которыми познакомился в статьях Джузеппе Кубони, его профессора в Пизе. Реализации идей Н. Стрампелли противостоял академический истеблишмент, и в частности профессор Франческо Тодаро (Francesco Todaro) выдающийся профессор агрономии в Болонье и, безусловно, самый аккредитованный генетический исследователь начала века. Франческо Тодаро не верил в полезность скрещиваний, отдавал предпочтение медленному отбору мутантных индивидуумов с интересными признаками в уже имевшихся тогда сортах (Mariani, 2015).

Но результаты работы Н. Стрампелли по скрещиванию местных сортов различного происхождения были настолько успешны, что он смог преодолеть скептическое отношение к своему методу, который называли быстро проходящей модой, и продолжить свои исследования. Его первый сорт мягкой пшеницы Carlotta (Rieti $\times$ Massy) был высокоурожайным в условиях более холодно- го климата и засухи, но высокорослым и позднеспелым. Целью Н. Стрампелли была скороспелая пшеница с коротким стеблем (устойчивая к полеганию) и мало восприимчивая к ржавчине. Следующий сорт Ardito - первый большой успех Н. Стрампелли. Среди разнообразных сортов пшеницы, которые Н. Стрампелли оценил в Риети, особенно привлек его внимание японский сорт Akagomughi. Н. Стрампелли получил бесплатный образец его семян в 1911 г. от компании Ingegnoli в Милане (Strampelli, 1932). Сорт не имел агрономической ценности, но был короткостебельным (обладал геном Rht8) и скороспелым (благодаря гену Ppd-D1) (Bianchi, 1995; Borojevic, Borojevic 2005a, b). В 1913 г. Н. Стрампелли скрестил линию Selezione 21, полученную в результате скрещивания устойчивого к ржавчине Rieti и высокоурожайного сорта Wilhelmina Tarwe c Akagomughi. В итоге был создан сорт Ardito короткостебельный и, следовательно, устойчивый к полеганию сорт с высоким уровнем устойчивости к ржавчине, раннее созревание которого позволяло ему избегать стресса от засухи во время налива зерна. Селекционер добился своей цели.

Для своей работы Н. Стрампелли собрал около 250 местных сортов со всех частей планеты. Используя их, сделал около 800 комбинаций кросс и бэккросс скрещиваний, фенотипировал миллион растений и десятки тысяч константных линий по нескольким хозяйственно важным признакам и создал более 60 сортов мягкой пшеницы, некоторые из которых называли элитными (Boggini et al., 2004; Scarascia Mugnozza, 2005; Lusiani, 2015; Salvi, 2016b). Его новые сорта быстро распространились в странах Южной и Восточной Европы, бассейне Средиземного моря, Южной Америке и Китае, что позволило внедрить инновации в создание сортов пшеницы, которые стали традицией и изменили способ ее выращивания во всем мире (Capone, 2016). Работа Н. Стрампелли позволила Италии стать почти самодостаточной в производстве хлебной пшеницы. За успехи, достигнутые в генетическом улучшении пшеницы, и создание инновационных высокоурожайных сортов Н. Стрампелли был назван «магом пшеницы» (il mago del grano). Даже за рубежом он стал известен как «волшебник пшеницы» (the wheat wizard), когда в 1934 г. его сорт мягкой пшеницы Damiano Chiesa побил мировой рекорд по урожайности зерновых: 73 центнера с гектара (Defez, Salvi, 2016). Эскалация пшеницы Н. Стрампелли была поистине экстраординарной и не имела сопоставимых примеров в мире (Lorenzetti, 2000a).

Н. Стрампелли был первым европейским ученым, включившим японские сорта в свою селекционную работу. Он был предшественником Зеленой революции конца 1960-х гг. и отцом ее первой фазы; отцом второй фазы Зеленой революции справедливо считается Норман Эрнест Борлауг (Norman Ernest Borlaug) (Lorenzetti, 2000a, b; Salvi et al., 2013; Giorgi, 2014).

\section{Senatore Cappelli - краткая история прославленной пшеницы durum}

Для большинства итальянцев самым большим достижением исследований Н. Стрампелли остается твердая пшеница Senatore Cappelli. B 1907 г. депутат Королевства Италии Раффаэле Каппелли (Raffaele Cappelli), автор аграрной реформы начала двадцатого века, начавший модернизацию сельского хозяйства в Апулии, владелец многочисленных ферм, решил использовать одну из них для экспериментального выращивания. Он предложил Н. Стрампелли проводить экспериментальные посевы на своих полях близ Фоджи (Foggia). Н. Стрампелли без колебаний принял 
это предложение (Lusiani, 2015). До начала 1910 г. он разработал программу по генетическому улучшению твердой пшеницы, изначально основанную на отборе чистых линий из местных сортов, выращиваемых в Южной Италии, на итальянских островах и в Средиземноморье. В 1915 г. он создал сорт с хорошими адаптивными свойствами, пригодный для приготовления макарон, полученный генеалогическим отбором из местного тунисского сорта Jenah Rhetifah, который в 1923 г. был выпущен в производство и назван в честь Р. Каппелли - Senatore Cappelli. Основная заслуга сенатора состоит в том, что его не подвела интуиция, когда он давал Н. Стрампелли разрешение на проведение экспериментов на своих полях. В свою очередь Н. Стрампелли не подвела его интуиция при отборе чистых линий с необходимыми характеристиками.

Н. Стрампелли создает другие сорта твердой пшеницы, полученные отбором из местных сортов, такие как Tripolino и Milazzo (Сицилия), Aziziah 17-45 (Палестина) и сорт Garigliano, полученный от скрещивания Tripolino $\times$ Cappelli. Но именно Cappelli имел успех среди итальянских фермеров благодаря его широкой адаптивности, неприхотливости к бедным глинистым почвам, отличным питательным качествам и высокой белковой ценности, несмотря на то что он высокорослый и склонен к полеганию. В Апулии эти характеристики обеспечили сорту прозвище «мясо бедных» (carne dei poveri). Его внедрение повысило среднюю урожайность с 0.9 т/га в 1920 г. до 1.2 т/га в конце 1930-х гг. (Maliani, 1998). В Италии в течение нескольких десятилетий Cappelli выращивался на большей части посевных площадей, занятых твердой пшеницей (до 60 \%), и широко выращивался в средиземноморских странах. Сорт присутствует в родословной почти всех сортов твердой пшеницы Италии и других стран. Спустя почти столетие он все еще выращивался в регионах Южной Италии, например в Базиликате (Basilicata), как источник семолины для производства выдающейся пасты (Scarascia Mugnozza, 2005; Bressanini, 2010). Senatore Cappelli был в Национальном реестре культивируемых видов и сортов Италии в 1981 г., спустя почти 70 лет после начала его выращивания, и возделывался на протяжении 90 лет (Deidda et al., 2001).

\section{Признание научных заслуг Назарено Стрампелли}

На самом деле научное величие Н. Стрампелли заключается не в создании Cappelli, а в инновационном мышлении, понимании того, что с помощью скрещиваний можно собрать много полезных генов, очистить линии от нежелательных признаков и создать в итоге улучшенный сорт. Он был новатором, который занимался конкретной наукой и использовал ее для борьбы с одной из фундаментальных проблем человеческого существования - голодом. Однако долгое время мало кто соглашался с тем, что итальянский генетик заслуживает признания настоящего ученого: это было поставлено под сомнение его современниками из-за малого количества научных работ и того факта, что большое количество исследовательских работ по кормовым, садовым и техническим культурам никогда не были опубликованы (Strampelli, 1932). Но постепенно признание глобальной важности результатов Н. Стрампелли в селекции пшеницы и их положительного влияния на современную селекцию растений прогрессировало (Braun et al., 1997; Borojevic, 2003). Американский генетик Уоррен Кронстад (Warren Kronstad) вспомнил об этом во время пятой международной конференции по пшенице, состоявшейся в Анкаре в 1996 г., подчеркнув, что Н. Стрампелли был первым ученым в мире, который использовал японские сорта, такие как Akakomughi. Уго Де Киллис писал, что опыт Н. Стрампелли был уникальным как для достигнутых результатов, так и для времени, в которое они были достигнуты, что находилось в явном противоречии с обычной тенденцией представления результатов, предполагающих длительное время адаптации и акклиматизации (De Cillis, 1942). Исключительная актуальность работы Н. Стрампелли стала лучшим свидетельством научной ценности человека и полностью подтверждает его роль предшественника Зеленой революции и статус подлинного ученого, который должен получить всеобщее признание (Salvi et al., 2013).

О Н. Стрампелли написаны книги и статьи его биографом Серджио Сальви (Sergio Salvi): «По следам Назарено Стрампелли» (Salvi, 2013), «Человек, который хотел накормить мир: первые 150 лет Назарено Стрампелли» (Salvi, 2016a), «Бедный Назарено Стрампелли, "пленник" пшеницы Каппелли...!» (Salvi, 2016b) и другие. С. Сальви, биолог по образованию, исследователь в области генетики, в настоящее время занимается исследованиями и историко-научным распространением вопросов, касающихся агропродовольственного сектора и, в частности, сельскохозяйственной генетики: историко-научная биография Н. Стрампелли, происхождение и эволюция традиционных сортов пшеницы, концепция типичного продукта, восстановление сельскохозяйственных сортов, представляющих исторический интерес. Он является членом-корреспондентом Депутации национальной истории (Deputazione di Storia Patria) региона Марке.

В 2009 г. режиссер Джанкарло Баудена (Giancarlo Baudena) снял фильм «Человек пшеницы» (L’Uomo del grano). Он рассказывает о жизни Н. Стрампелли как одного из величайших генетиков всех времен. Фильм был показан на Всемирной выставке 2015 г. в Милане (Esposizione Universale Milano 2015) и проиллюстрировал главную тему «Экспо2015»: «Накормить планету - дать энергию для жизни» (Nutrire il Pianeta, Energia per la Vita).

В 2016 г. в честь 150-летия Н. Стрампелли в Италии в сельскохозяйственном институте Джузеппе Гарибальди в Мачерате (Macerata, Regione Marche) состоялось мероприятие «Buon Compleanno Nazareno Strampelli» - «С Днем рождения, Назарено Стрампелли!» Юбилей был организован Георгиевской академией Треи (Accademia Georgica Treia). Технические и научные моменты конференции были инициированы доктором С. Сальви. Он выступил с презентацией своей книги, изданной академией (Salvi, 2016а). Выдающиеся исследования Н. Стрампелли и ценность его наследия были подчеркнуты в докладах профессора сельскохозяйственной генетики Роберто Пара «Сельское хозяйство сталкивается с проблемами продовольственной безопасности, изменения климата и устойчивости: урок генетика Назарено Стрампелли» (Para, 2016), доктора Ориана Порфири «Пшеницы Стрампелли через столетие после их создания» (Porfiri, 2016), профессора генетики растений Римского университета Ла Сапиенца Норберто Поньи «Генетическое улучшение пшеницы и наследие Назарено Стрампелли» (Pogna, 2016).

В 1919 г. Н. Стрампелли создал Национальный институт генетики злаковых культур (Istituto Nazionale di Genetica per la Cerealicoltura, INGC), базирующийся в Риме, и руководил им до своей смерти (рис. 2).

В состав института вошли фитотехнические станции в следующих городах: в 1919 г. - в Фодже (рис. 3), в 1920 г. - в Палермо (Palermo) 


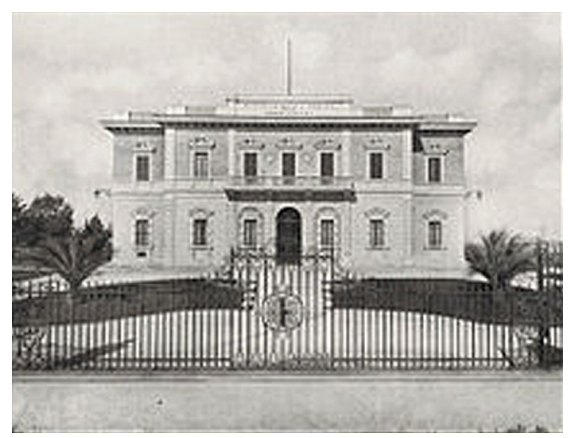

Рис. 2. Национальный институт генетики злаковых культур, Рим (источник: https://it.wikipedia.org/wiki/Istituto_nazionale_di_genetica_per_la_cerealicoltura).

Fig. 2. National Genetic Institute for Cereal Culture, Roma (a source: https://it.wikipedia.org/wiki/Istituto_nazionale_di_genetica_ per_la_cerealicoltura).

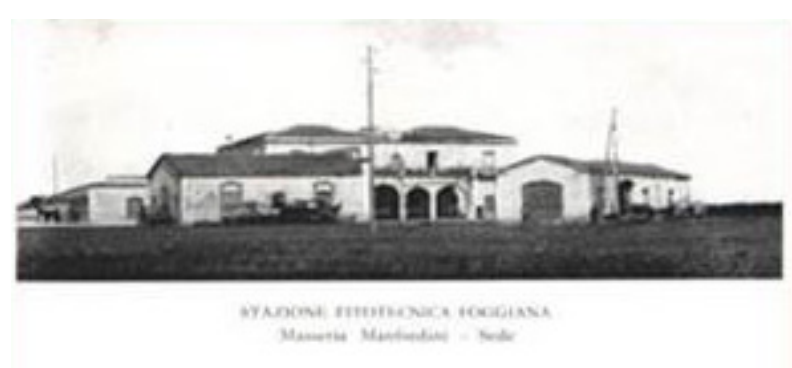

I. Staniose Fitorevinica per le Paglie

Рис. 3. Фитотехническая станция в Фодже (Апулия) (источник: http://qce.entecra.it/sezioni/Foggia.htm). Fig. 3. Phytotechnical station in Foggia (Puglie) (a source: http://qce.entecra.it/sezioni/Foggia.htm).

и Риме (Roma), в 1928 г. - в Кальяри (Cagliari), в 1937 г. - в БадииПолезине (Badia Polesina), Монтаньяне (Montagnana), Урбино (Urbino) и Форли (Forlì).

В 1933 г. графиня Лидия Капрара (Lydia Caprara) пожертвовала INGC сельскохозяйственный фонд Morando Bolognini в 400 га, названный в честь ее мужа, для создания фитотехнической станции для Северной Италии и передала замок Sant'Angelo Lodigiano музею института. Следует отметить, что деятельность станции в Фодже (Stazione Fitotecnica per le Puglie) была сосредоточена на размножении и сохранении в чистоте новых сортов мягкой пшеницы, созданных Н. Стрампелли в Риети, и где позже была осуществлена программа интенсивного генетического улучшения твердой пшеницы.

В 1968 г. в результате слияния INGC и двух экспериментальных станций по выращиванию риса в Верчелли (Vercelli) и кукурузы в Бергамо (Bergamo), основанных в 1908 и 1920 гг. соответственно, был создан Экспериментальный институт зерновых культур (Istituto Sperimentale per la Cerealicoltura, ISC). Институт имел четыре отделения: прикладная генетика, маркетинг продукции, агрономические методы и планирование экспериментов. Основные задачи ISC - проведение исследований в области генетики, генетического улучшения сортов и методов их выращивания, выработка категорий качества продукции зерновых культур. При этом фитотехническая станция в Фодже была преобразована в периферийное отделение ISC - Sezione Operativa Periferica dell'Istituto Sperimentale per la Cerealicoltura. В августе 2007 г. отделение в
Фодже стало Научно-исследовательским центром зерновых культур (Centro di Ricerca per la Cerealicoltura, CER).

В 2015 г. Совет по сельскохозяйственным исследованиям и анализу аграрной экономики (Consiglio per la ricerca in agricoltura e I'analisi dell'economia agraria, CREA) провел функциональную реорганизацию CER, преобразовав его в Исследовательский отдел по улучшению качества зерновых (L'Unità di Ricerca per la Valorizzazione Qualitativa dei Cereali, CER-QCE). ). Сегодня этот отдел входит в состав Национального института генетики злаковых культур (Istituto Nazionale di Genetica per la Cerealicoltura, INGC).

Целью реорганизации, проведенной CREA в 2015 г., было устранение дублирования и рационализация экономических и кадровых ресурсов. Это позволило обеспечить жизнь 12 исследовательским центрам, 6 из которых - межотраслевые центры, а другие 6 - сеть центров по отдельным культурам и лесу. В состав межотраслевых центров входят исследовательские центры геномики и биоинформатики, сельского хозяйства и окружающей среды, защиты и сертификации, инженерных исследований и переработки сельскохозяйственной продукции, пищевых продуктов и питания, политики и биоэкономики. Межотраслевым центрам поручены миссии, связанные со сквозными аспектами сельского хозяйства, касающимися агропродовольственного сектора и агропромышленного комплекса, продовольствия и питания, европейской и национальной сельскохозяйственной политики. У остальных центров специальные миссии, в частности - по улучшению качества итальянских продуктов (Centri di Ricerca CREA, 2019).

\section{Селекция твердой пшеницы в Италии после Назарено Стрампелли}

Проект Н. Стрампелли по генетическому улучшению твердой пшеницы был продолжен после его смерти в INGC и региональных отделениях исследователями, которые в середине столетия создали новые сорта. Были созданы возможности для обеспечения сильного импульса фундаментальных исследований твердой пшеницы и активизации селекционной деятельности. Так, в 1940-1960-х гг. Ф. Казале (F. Casale) создал сорта Patrizio и Capeiti 8, отобранные из скрещивания Cappelli и палестинского сорта Eiti. Capeiti 8 ниже Cappelli и более скороспелый, но с плохими макаронными качествами (Casale, 1955). R. Forlani (1945) показала необходимость увеличения генетической изменчивости в итальянской твердой пшенице с помощью межвидовых скрещиваний. G. Conti (1948), работавшему на сельскохозяйственной опытной станции в Бари (Stazione Sperimentale Agricola di Bari), удалось отобрать интересные линии от Aziziah, а из знаменитой российской твердой пшеницы Таганрог ${ }^{1}$ создать серию сортов Russello, которые в основном выращивались на Сицилии и в Южной Италии (De Cillis, 1964; D’Amato, 1989). R. Grifoni (1964) выбрал из созданных им многочисленных линий сорта Grifoni 234 и Grifoni 235 (Cappelli × Aziziah), которые на Апулийской равнине (la Pianura Pugliese) показали большую урожайность и устойчивость к полеганию, чем сорт Cappelli. Оптимальные качество зерна и урожайность были достигнуты в Южной Италии при выращивании сорта Appulo, созданного Р. Грифони в 1964 г. после отбора линий, полученных из гибрида [(Cappelli $\times$ Grifoni 235) $\times$ Capeiti] (Grifoni, 1964). К списку сортов, созданных в конце 1960-х гг., мож-

\footnotetext{
1 Таганрог- объединенное название, данное в начале XX в. за рубежом различным российским коммерческим поставкам твердой пшеницы, экспорт которых осуществлялся, в основном, через порт Таганрога.
} 
но добавить такие как Karel, Maristella, Nuragus, Ottava и Ichnusa, подходящие для условий засухи Сардинии (Barbieri, Deidda, 1968), и Trinakria с превосходным качеством макаронных изделий (Ballatore, 1970). Они характеризовались хорошей урожайностью, хорошим качеством и приспособляемостью к климатическим условиям Южной Италии. В частности, Karel характеризовался как высоким уровнем производства, так и стабильностью производства, превышающей стабильность производства Creso - короткостебельного и более скороспелого, чем другие сорта-карлики или полукарлики, но мелкозерного и среднего качества.

Новый сорт ISA-1 (Dionigi, 1971), созданный в Апулии, характеризовался скороспелостью и, таким образом, позволял избежать стресса засухи, хотя его урожайность и качество не соответствовали предпочтениям фермеров.

Следовательно, начиная с 1970-х гг., повышение урожайности стало основной целью многих селекционных программ, которые должны были быть достигнуты путем интрогрессии полезных признаков от гексаплоидных и диких видов пшеницы или с помощью программ мутагенеза, стимулирующих селекционную стратегию, принятую селекционерами после Второй мировой войны и направленную на уменьшение количества стеблей на растении, увеличение числа колосьев на единицу площади, короткостебельность, высокую фертильность, повышение индекса урожая (Porceddu, Blanco, 2014).

В 1970-х гг. многие исследователи пытались улучшить качества твердой пшеницы с помощью межвидовых скрещиваний. Были достигнуты явные успехи в отношении устойчивости к болезням, холоду и полеганию, а также к снижению процента мучнистых пятен на разрезе стекловидного зерна (yellow berry - желтая ягода). A. Alessandroni, B. Rusmini и M.C. Scalfati (1966) использовали диплоидные и гексаплоидные виды пшеницы, такие как T. dicoccum, T. turgidum, T. sphaerococcum и другие, в качестве источника устойчивости к патогенам, холоду и полеганию, а также для повышения фертильности колоса. J. Vallega и G. Zitelli (1973) разработали селекционную программу с использованием генов устойчивости к ржавчине, мучнистой росе и септории, присутствующих в других видахпшеницы и эгилопсах. В начале 1970-хгг. были созданы сорта Valgerardo, Valgiorgio, Valselva и другие, обладающие не только высокой устойчивостью к болезням, но и высоким потенциалом продуктивности, с хорошей адаптивностью и необходимым качеством (Vallega et al., 1974).

Особого внимания заслуживает деятельность Экспериментальной станции зерновых культур на Сицилии (La Stazione Sperimentale di Granicoltura per la Sicilia), где твердая пшеница является приоритетной зерновой культурой для исследования и создания новых сортов (рис. 4-6).

Профессор Уго Де Киллис (Ugo De Cillis) (рис. 7) с 1929 по 1948 г. был директором Экспериментальной станции зерновых культур на Сицилии, а с 1948 по 1971 г. возглавлял Национальный институт исследований зерновых культур. Его книга «Пшеницы Сицилии» (De Cillis, 1942) свидетельствует об усилиях, предпринимаемых станцией для сохранения ценных растительных ресурсов - наследия Сицилии и всего человечества. Одной из основных задач станции является содействие генетическому улучшению твердой пшеницы. В естественной сицилийской популяции сотрудниками станции были выполнены отборы многих чистых линий, которые они использовали для скрещиваний как лучшие родительские формы (таблица, рис. 8).

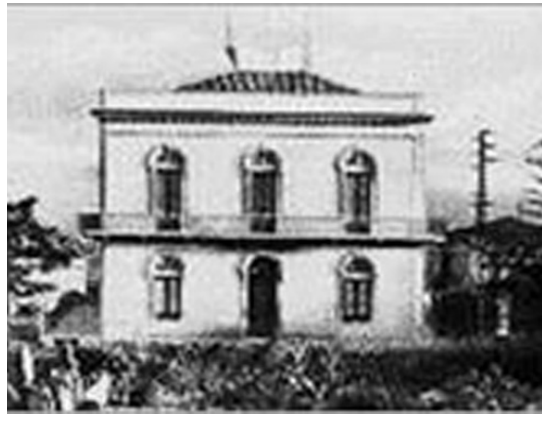

Рис. 4. Центральный офис станции в 1931 г., Катания (источник: http://www.granicoltura.it/p_storia.html). Fig. 4. Station Central Office in 1931, Catania (a source: http://www.granicoltura.it/p_storia.html).

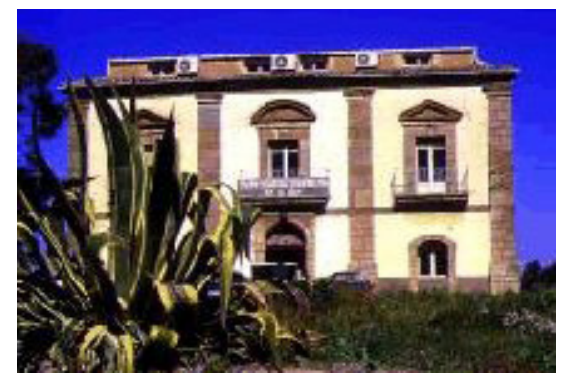

Рис. 5. Центральный офис станции в 1975 г., Кальтаджироне (источник: http://www.granicoltura.it/p_storia.html). Fig. 5. Station Central Office in 1975, Caltagirone (a source: http://www.granicoltura.it/p_storia.html).

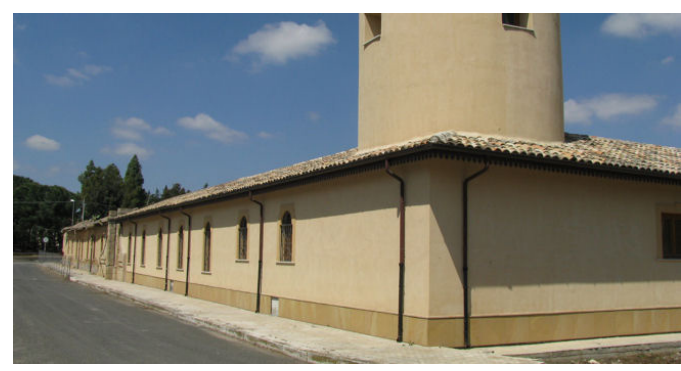

Рис. 6. Центральный офис станции с 2011 г., Санто Пьетро (источник: http://www.granicoltura.it/p_storia.html).

Fig. 6. Station Central Office since 2011, Santo Pietro (a source: http://www.granicoltura.it/p_storia.html).

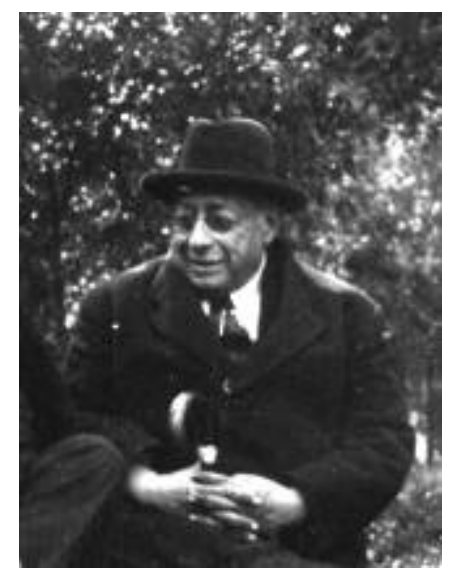

Рис. 7. Профессор Уго Де Киллис (1901-1984) (источник: http://www.granicoltura.it/p_storia.html). Fig. 7. Prof. Ugo De Cillis (1901-1984) (a source: http://www.granicoltura.it/p_storia.html). 


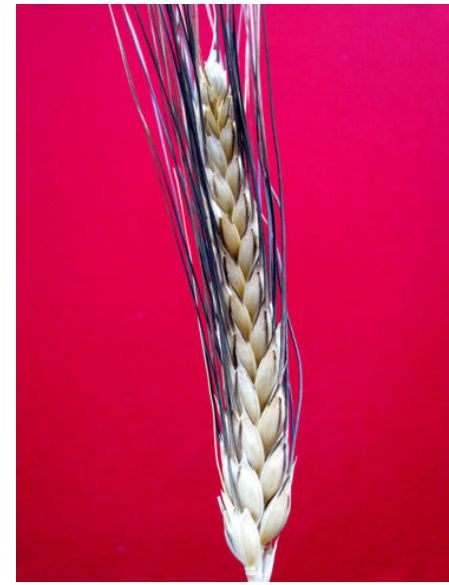

TIMILIA



BIANCUCCIA

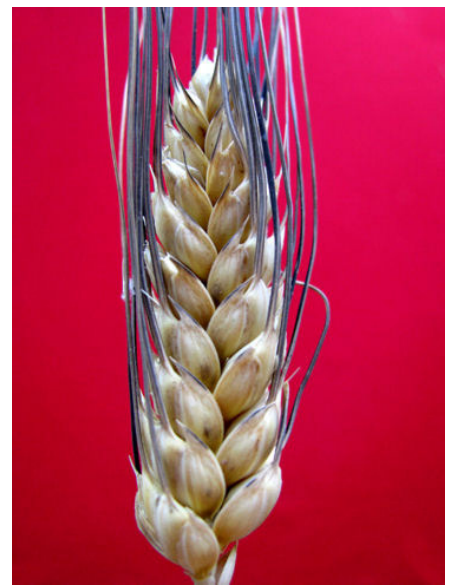

TRENTINO

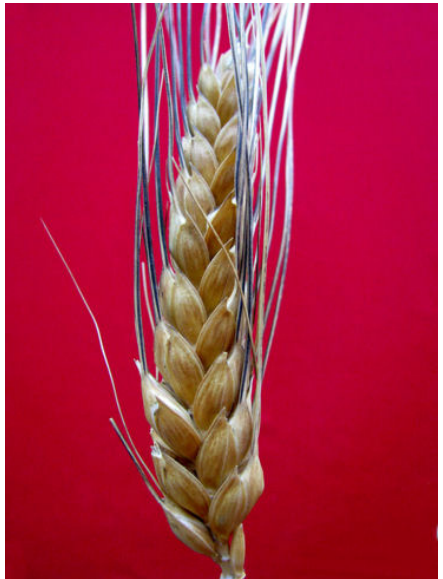

RUSSELLO

Pис. 8. Старые местные итальянские сорта, вошедшие в родословные современных сортов (источник: http://www.granicoltura.it/p_germoplasma.html). Fig. 8. Italian landrace included in the pedigrees of modern varieties (a source: http://www.granicoltura.it/p_germoplasma.html).

Список скрещиваний с использованием чистых линий твердой пшеницы, отобранных на станции

List of crossing using pure durum wheat lines selected at the station

\begin{tabular}{lll} 
& \multicolumn{2}{c}{ Crossing } \\
Russello $\times$ Eiti 6 & Bufala rossa lunga $\times$ Eiti 6 & Russello $\times$ Bidì \\
\hline Eiti $6 \times$ Timilia & Bidì $\times$ Abu-Fashi & Timilia $\times$ Regina \\
\hline Eiti $\times$ Sammartinara & Bidì $\times$ Timilia & Timilia $\times$ Biancuccia \\
\hline Eiti $\times$ Cappelli & Bidì $\times$ Trentino & Relforte $\times$ Psathas \\
\hline Azizia $\times$ Cappelli & Bidì $\times$ Ruscia & Timilia $\times$ Urria \\
\hline Bufala $\times$ Eiti & Bidì $\times$ Biancuccia & Sueda $\times$ Biancuccia
\end{tabular}

В результате на станции в разные годы были созданы следующие сорта твердой пшеницы: в 1930-е гг. - Russello SG7, Timilia SG1 и Timilia SG2 (внутрипопуляционная селекция); в 1940-е гг. - Timilia SG3 и Duro SG3 (VL Biancuccia × Timilia); в 1960-е гг. - Casale 92, Vera 63, Galatea 9, Patrizio 6, Capeiti 8 и Ciclope 66; в 1980-е гг. - Simeto, Alcantara и Platani; в 2000-е гг. - Tumminia SG3 и Russello SG8 (внутрипопуляционная селекция).

Сорт твердой пшеницы Timilia, или Tumminìa, которому более 2500 лет, - очень ценный сорт, типичен для региона Энны (Enna), находится под угрозой исчезновения. Путем отбора из него были созданы два сорта: один с черными остями (Timilia S.G.1 a reste nere), другой - с белыми (Timilia S.G.2 a reste bianche) (De Cillis, 1964). Слово «timilia» означает «ежеквартально». На самом деле вегетационный период этого сорта составляет всего три месяца, и он широко использовался в дождливые годы, когда посев был поздним.

Timilia также ценится за высокую урожайность и силу муки, но его коммерческая ценность мала, поскольку он дает муку очень темного цвета. Тем не менее из неё делают черный хлеб - круглый каравай, называемый в Сицилии «vastedda». Этот традиционный сицилийский хлеб, наиболее распространенный в городе Палермо, используется для приготовления pani câ meusa - бутерброда с селезенкой из телятины, - либо с сырами caciocavallo и ricotta. Большой популярностью пользуется домашний формовой хлеб Lentini c семенами кунжута на поверхности. По традиции к крупке из твердой пшеницы добавляют часть муки «тимилии», что обусловливает более длительный срок хранения хлеба.
Сегодня, когда актуальным является вопрос сохранения и использования старых местных сортов, нужно упомянуть о значительной работе сотрудников CER - книге «Древняя сицилийская пшеница - первое техническое руководство по распознаванию местных сортов сицилийской пшеницы» (Venora, Blangiforti, 2017) (рис. 9). Это важный вклад в укрепление уникального культурного и продовольственного наследия, которое сделало и делает Сицилию естественным перекрестком новой революции, нового понимания пищи, книга, которая пытается построить мост между традициями прошлого и вызовами будущего. Во вступлении к книге Умберто Анастаси (Umberto Anastasi) и Паоло Гуарначча (Paolo Guarnaccia), профессора Катанийского университета, отмечают, что старые местные сорта сицилийской пшеницы составляют генетическое наследие, которое имеет исключительную научную и культурную ценность, благодаря которому можно противостоять проблеме изменяющегося климата, сохранить уникальность питательных и биологически активных веществ и содержат в себе информацию о пути эволюции пшеницы для познания будущими поколениями исследователей. Необходимо пояснить, что в Италии называют древними зернами пшеницы (grani antichi) и за что они ценятся сегодня. Это все сорта пшеницы, которые выращивались до того, как селекционеры начали создавать сорта для промышленных целей, начиная примерно с 1970-х гг. Из пшеницы Senatore Cappelli было бы невозможно производить промышленную пасту: она слишком легко ломалась из-за низкого содержания глютена (клейковины). Со- 

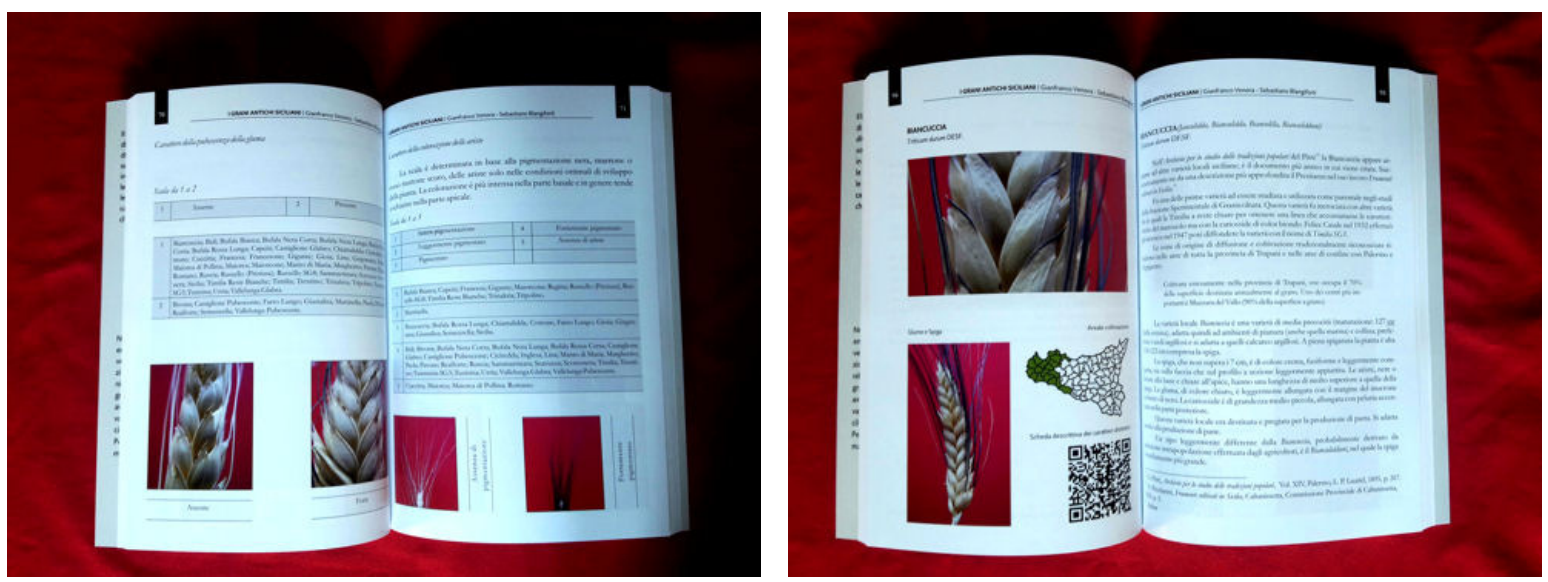

Рис. 9. Книга «Древняя сицилийская пшеница» (I Grani Antichi Siciliani) источник: http://www.granicoltura.it).

Fig. 9. The book "The Ancient Sicilian Grains" (I Grani Antichi Siciliani) (a source: http://www.granicoltura.it).

временные сорта в первую очередь имеют гораздо более высокий индекс глютена и дают более эластичное тесто, устойчивое к тепловым ударам, что сокращает время производственного процесса. Но вкус и аромат практически исчезли из критериев отбора в связи с использованием очень рафинированной муки. Сегодня итальянские потребители считают, что современные сорта несут ответственность за распространение целиакии и непереносимости пшеницы. Целиакия - это заболевание, при котором глютен не только не расщепляется, но и вызывает иммунную реакцию организма. Разнообразие проявлений этого генетического заболевания стало одной из причин недавно начавшейся паники вокруг глютена. Различия в структуре глютена обсуждались и будут обсуждаться снова, но до сегодняшнего дня исследования, проводимые на различных популяциях населения, свидетельствовали о том, что древние зерна раздражают кишечник меньше, чем современные. Еще не до конца ясно, происходит ли это из-за глютена, поэтому сегодня больше не говорят о непереносимости глютена, а говорят о непереносимости пшеницы (Lusiani, 2017). Поэтому в последние годы старые местные сорта, как и те, которые были созданы Н. Стрампелли, переживают вторую молодость, особенно в органических цепях (Ляпунова, 2018).

В начале 1960-хгг.урожай твердой пшеницы, благодаря улучшению агрономической практики, хотя и составлял около 1.8-2.0т/га, был намного ниже, чем урожай хлебной (мягкой) пшеницы. Сорта твердой пшеницы имели более высокую цену за качество макаронных изделий, но культура была убыточной даже для фермеров Южной Италии, в основном из-за низкой урожайности и недостаточной реакции на удобрения. Это вызвало устойчивое уменьшение посевных площадей и отсутствие внимания со стороны генетиков и физиологов растений. Твердую пшеницу можно определить как «вид-сироту» для научных исследований в области генетики, физиологии сельскохозяйственных культур, технологического качества (Scarascia Mugnozza, 2005). Скрещивания между филогенетически очень близкими сортами, которые принесли большой прогресс, уже было недостаточно. Необходимы были исследования, которые способствовали бы познанию генетики вида, как теоретические, так и практические, определяющие показатели влияния на продуктивность и адаптивность к сложным агроэкологическим условиям, а также помогли бы улучшить качество твердой пшеницы. Результаты исследований предна-



Рис. 10. Профессор Франческо Д'Амато (1916-1998) (источник: Scarascia Mugnozza, 2005).

Fig. 10. Prof. Francesco D'Amato (1916-1998) (a source: Scarascia Mugnozza, 2005).

значались для использования в селекционных программах для получения сортов, наиболее подходящих для выращивания. Для реализации этих целей в 1958 г. в Лаборатории генетики растений и мутагенеза в Центре ядерных исследований Касачии (Centro Ricerche Nucleari della Casaccia, ENEA) Национального комитета по ядерной энергии (CNEN) был разработан и реализован исследовательский проект научного консультанта Ф. Д'Амато и директора лаборатории Дж.T. Скараши Муньоццы (G.T. Scarascia Mugnozza).

Франческо Д'Амато (Francesco D’Amato) (рис. 10) - это ученый, имевший большое международное признание в области естественных наук: ботаники, цитогенетики, биологии развития; доктор естественных наук, почетный доктор сельскохозяйственных наук, профессор ботаники, директор института ботаники университета Кальяри (1957-1959 гг.); профессор генетики, директор Института генетики Пизанского университета (1959-1991 гг.); лауреат одной из самых престижных премий Италии - премии Фельтринелли (Premio Feltrinelli) Национальной академии деи Линчеи (Accademia Nazionale dei Lincei) в области ботаники (1956 г.) и прикладной биологии (1981 г.). Это одна из старейших академий наук Европы, она основана в 1603 г. Академики называют себя «рысьеглазыми» (lincei) в знак признания особой зоркости зрения, кото- 
рая необходима для научного познания и которая особо присуща рыси. Научный интерес к мутагенезу у Ф. Д'Амато появился после участия в исследованиях по радиогенетике и химическому мутагенезу диплоидных видов Hordeum vulgare в лаборатории Шведской ассоциации семеноводов в Свалеве под руководством профессора А. Густафссона (A. Gustafsson).

Проект D’Amato - Scarascia Mugnozza преследовал две цели: использовать твердую пшеницу в качестве модельного растения для исследований в области генетики, цитогенетики и мутагенеза и увеличить изменчивость вида путем индукции и отбора полезных мутаций (D’Amato, 1992). Эти цели были направлены на разработку исследований и методов для практического применения посредством проведения широких полевых экспериментов с генотипами, лабораторный анализ которых показал их полезность для генетического улучшения твердой пшеницы. Зерновки сортов твердой пшеницы Cappelli, Aziziah, Capeiti, Garigliano, Russello, Grifoni облучали различными дозами рентгеновских лучей, тепловых нейтронов, быстрых нейтронов или обрабатывали различными концентрациями химических мутагенов. Полученные мутанты несли аллели для исправления дефектов, таких как восприимчивость к полеганию и задержка колошения, и использовались для создания сортов, обладающих более высокой урожайностью и хорошей адаптацией к агроэкологии. Интересные результаты были получены при изучении наследственной основы количественных признаков, связанных с урожайностью зерна: дата колошения, количество колосков на главном колосе, длина колоса, масса зерна, количество стеблей, длина стебля и продолжительность фаз вегетационного периода (Bagnara, Scarascia Mugnozza, 1973). Ф. Д'Амато показал, что твердая пшеница, в то время считавшаяся в международной литературе «Золушкой», оказалась отличным материалом для приобретения знаний об общем характере культуры. Выделенные мутации составили материал для обширных генетических, цитогенетических, биохимических и физиологических исследований в Центре Касачии (Casaccia) и других местах. Мутанты и сегрегационные поколения после скрещивания мутантов с сортами подвергались многолетним агрономическим тестам, и были выделены новые сорта твердой пшеницы. Они улучшили производство в Италии и других странах, где некоторые из них использовались в качестве родительских линий в селекционных программах для получения короткостебельных сортов твердой пшеницы во Франции, Австрии (Gandur и Unidur), Греции, Болгарии (Lozen, Sredets и др.), а также в США в качестве родителей сортов синтетической культуры тритикале (Scarascia Mugnozza et al., 1993). Несколько новых сортов были испытаны в рамках программы FAO-IAEA-CNEN «Оценка мутантных линий твердой пшеницы в бассейне Средиземного моря». Основными участниками этой программы были: лаборатория CNEN (Casaccia Roma) - G.T. Scarascia Mugnozza, D. Bagnara, A. Bozzini, C. Mosconi; IAEA (МАГАТЭ) (Vienna) - B. Sigurbljornsson, P.T. Bogyo; FAO (Rome) J. Tessi. Испытания проводились в течение пяти лет (1966-1970 гг.) в 35 местах (от Марокко до Пакистана и Индии) на 13 сортах: 9 мутантных линиях и 4 контрольных сортах (двух местных и двух широко культивируемых итальянских сортах). Материал оценивали по 15 показателям полевой оценки, включая устойчивость к желтой ржавчине (Bogyo et al., 1974). В Центре Касачии некоторые из лучших мутантов были зарегистрированы как новые сорта серии Castel: Castelporziano и Castelfusano из Cappelli, Casteldelmonte из Grifoni, Castelnuovo из Garigliano. Castelporziano отличался от
Cappelli одним частично доминантным геном, способным уменьшить высоту на 34 \% (Bozzini, Scarascia Mugnozza, 1967). Благодаря своему эректоидному гену Castelporziano не полегает в самых неблагоприятных условиях выращивания.

CNRN-ENEA была разработана программа для изучения поведения новой индуцированной генетической изменчивости в зародышевой плазме пшеницы и были исследованы потомки от скрещивания тетраплоидной и гексаплоидной пшеницы для повышения общих знаний и размножения (Blanco et al., 1988; Bozzini, 1988).

В 1974 г. был создан сорт Creso, полученный от скрещивания мутантной короткостебельной линии твердой пшеницы СрВ144 и короткостебельной линии мягкой пшеницы из СIMMYT, несущей карликовые гены Rht 1 на хромосоме 4A от Norin 10. Этот сорт является наивысшей точкой генетических исследований, призванных восполнить разрыв между потенциалом урожайности твердой пшеницы и хлебной пшеницы в Италии. Фактически потенциал урожайности Creso несколько раз достигал 10 т/га, сохраняя в то же время хорошее качество зерна для производства макаронных изделий и устойчивость к Fusarium graminearum и нескольким расам бурой ржавчины (Bozzini, Bagnara, 1974). Можно сказать, что современные сорта пшеницы были рождены с созданием Creso, который до сих пор является пятым наиболее распространенным сортом твердой пшеницы в Италии (первые - Simeto, Duilio, Ciccio, Arcangelo). Он считается флагманом итальянских исследований, которые используются в программах генетического улучшения твердой пшеницы в США, Канаде, Австралии, Аргентине и Китае, а также в наиболее важных международных исследовательских центрах (Lusiani, 2017).

В результате реализации задач проекта Исследовательским центром Касачии было создано 22 зарегистрированных сорта твердой пшеницы, шесть из которых были получены в результате прямого отбора индуцированных мутантов, а остальные - в результате скрещивания (Scarascia Mugnozza et al., 1993).

В 1990-х гг. сотрудники секции ISC в Фодже разработали программы по изучению генетики и физиологии твердой пшеницы, селекции высокоурожайных сортов и улучшению качества. Были созданы сорта Ofanto, Lesina, Gargano, Venosa, занявшие свое место в производстве твердой пшеницы Италии в течение десятилетия. Среди физиологических параметров было уделено внимание повышению фотосинтетической активности и ее устойчивости, числу зерновок, транслокации и аккумуляции фотосинтеза в зернах. Особое внимание было уделено флаговому листу с широкой, но не длинной пластинкой, более длинному колосу с большим количеством колосков, крупным чешуям и длинным остям, долго сохраняющимся зелеными (Spano et al., 2003).

Помимо крупных исследовательских центров свой вклад в селекцию твердой пшеницы внесли частные фирмы и сельскохозяйственные факультеты университетов Южной Италии.

Сотрудники университетов Палермо, Сассари (Sassari) и Hеаполя (Napoli) создали уже упомянутые сорта твердой пшеницы, адаптированные к местным условиям, - Trinakria, Maristella, Ichnusa. В первой половине 1980-х гг. в университете Бари (Bari) Дж.Т. Скараша Муньоцца, А. Бланко и их коллеги создали сорта Messapia, Salentino и Salizia. Сорт Messapia значительно превосходил знаменитый Creso по скороспелости и продуктивности (Blanco et al., 1988). В поисках более быстрых и эффективных альтернатив традиционным методам селекции сотрудники университетов Бари и Витербо (Viterbo) создали карту генетических 
связей твердой пшеницы (Blanco et al., 1998; Lotti et al., 2000). В Болонском университете была проведена обширная работа по внедрению метода SSR-анализа для характеристики генетических расстояний среди образцов твердой пшеницы (Maccaferri et al., $2003,2005)$. Конечная цель этого исследования, основанного на SSR, состояла в том, чтобы идентифицировать большую группу генотипов, подходящих для поиска ассоциаций генотип - фенотип и картирования локусов количественных признаков (QTL), влияющих на агрономические признаки. Университеты проводят изучение диких видов подтриба Triticinae и переноса генов ценных признаков в твердую пшеницу. С цитогенетической и генетической точек зрения оценивают методики проведения таких переносов для достижения положительных результатов (Simeone et al., 2000). В университете Витербо осуществляются исследовательские проекты по генетическому анализу видов Aegilops L. (Giorgi et al., 2003) и по гибридизации Triticum durum Desf. с растениями диплоидного вида Dasypyrum villosum (L.) P. Candargy (De Pace et al., 2001).

Программы частных компаний в основном направлены на получение генотипов с высокой и стабильной урожайностью, устойчивых к биотическим и абиотическим стрессам.

Чирилло Малиани (Cirillo Maliani), итальянский генетик, иностранный член ВАСХНИЛ (1967), проделал замечательную работу с использованием межвидовых скрещиваний, главным образом с мягкой пшеницей, и получил высокоурожайные и высокопротеиновые сорта твердой пшеницы Viscardo, Montanari, Carlo Jucci, Giovanni Raineri (Maliani, 1968). На Сицилии селекционер П. Калканьо (P. Calcagno) создал высокоурожайные высококачественные сорта Simeto, Platani, Colosseo, Ciccio и Cannizzo, которые в основном выращиваются сегодня в Италии, Испании, Греции, Португалии и Северной Африке (Scarascia Mugnozza, 2005).

Семеноводческая компания Società Produttori Sementi (S.I.S.) в Болонье выпустила в 1990-х гг. сорт твердой пшеницы Lira - первый итальянский сорт, отобранный с использованием электрофореза глиадина в качестве маркера качества, сорт Zena - первый итальянский сорт, имеющий крупу высокого индекса желтого цвета, и copt Svevo - очень ранний и с исключительно высоким качеством для приготовления макарон. Частные семеноводческие компании Società Italiana Sementi (Bologna), Eurogen (Enna), ISEA (Ancona) и COSEME (Foggia) также принимали участие в реализации программ по созданию высокопродуктивных сортов твердой пшеницы.

Количество зарегистрированных сортов твердой пшеницы, которое было ниже 10 в начале 1980-х гг., выросло до 145 в 2001-2013 гг. благодаря финансовой поддержке ЕС, связанной с использованием зарегистрированных сортов семян и введением в Италии Национального реестра сортов. В 2013 г. Национальное агентство по сертификации семян (ENSE) сертифицировало более 200 тыс. т семян твердой пшеницы, причем наибольшая доля была у сорта Iride (12.4\%), затем - у сортов Simeto и Saragolla (11.4 и $9.3 \%$ соответственно); 76 \% сертифицированных семян принадлежали 20 сортам из 136 зарегистрированных. Creso спустя 35 лет все еще выращивался на 1.3 \% площади, предназначенной для сертифицированных семян твердой пшеницы (Porceddu, Blanco, 2014).

В последние годы большая доля сортов приходится на частные компании. В качестве примера можно привести семеноводческую компанию Apsovsementi S.p.A. (Voghera, Lombardia). Она была основана в 1967 г. группой фермеров Северной Италии с целью использовать свой опыт и климатические условия своей территории для создания и развития семенного бизнеса, основанного на производстве и сбыте высококачественных семян. Селекционные программы компании ориентированы на селекцию сортов с высокой урожайностью, наибольшей приспособляемостью к различным условиям внешней среды, с лучшим качеством и высокой устойчивостью к болезням. Эти цели достигаются с помощью очень эффективной селекционной программы, основанной на тестировании и скрещивании наилучшего сорта для каждого типа и агросреды, использовании разнообразного глобального банка генотипов. Отбор производится с эксклюзивным сочетанием различных методик с самыми передовыми методами молекулярного скрининга, позволяющими выявить и быстро отследить лучшие линии, которые станут новыми сортами. Поддержку селекционной деятельности оказывают широкие испытательные сети для скрининга и оценки ценности сортов и того, чтобы их качество отвечало потребностям производителя и рынка (Apsovsementi S.p.A., 2019).

Сегодня в каталоге компании 13 сортов твердой пшеницы: Diogene (2017), Platone (2016), Caboto (2016), Vespucci (2010), Teodorico (2014), Tirex (2007), Pitagora (2009), Kenobi (2012), Dylan (2002), Colombo (2010), Casanova (2003), Biensur (2000), Ariosto (2005). В предложении твердой пшеницы для крупного центрального и южного рынка доминируют очень известные сорта Colombo и Tirex, которые сочетают постоянную высокую продуктивность с качеством. Оба сорта имеют большой спрос у основных производителей макаронных изделий. Новый сорт Diogene наделен исключительной устойчивостью к листовым болезням. Другими интересными продуктами являются Teodorico и Kenobi, к которым добавлены две новинки: Caboto - среднеранний сорт, устойчивый к бурой ржавчине, с очень высокой урожайностью по всей территории страны, и Platone - поздний сорт, устойчивый к полеганию и фузариозу колоса, очень продуктивный в плодородных районах Северной и Центральной Италии, и поэтому уже вошедший в культуру во Франции. Оба сорта имеют ценные качественные характеристики (Apsovsementi varieties catalog, 2019).

\section{Основные направления селекции твердой пшеницы в Италии}

Селекция твердой пшеницы в Италии нацелена сегодня на улучшение таких признаков, как скороспелость, устойчивость к полеганию, устойчивость к болезням и вредителям, засухоустойчивость, а также на решение проблем ограниченного количества и одновременного снижения фертильных побегов, низкой фертильности колоска.

Селекционный прогресс в морфофизиологических и агрономических признаках сортов твердой пшеницы, созданных в Италии в XX в., был исследован P. De Vita и его коллегами (2007). Они показали, что генетический выигрыш наиболее четко ассоциируется с более высоким числом зерновок на квадратный метр, что указывает на необходимое увеличение числа зерен и числа колосков в колосе.

\section{Короткостебельность}

Постепенное уменьшение высоты растений, связанное у злаков с увеличением индекса урожая (НI), сопровождаемое эффектом увеличения мощности потока и распределения биомассы, также является одной из основных целей селекции. В 1960-х и 1970-х гг., одновременно с производством синтетических удобрений, которые не могли быть полностью использованы высокорослыми сортами из-за полегания, которое они вызывали, была выявлена 
группа основных генов (Rht, reduced heigth), называемая в целом «карликовыми генами». Первоначальный эффект от введения карликовых генов в твердую пшеницу часто был отрицательным, а успех был достигнут, когда генетический фон, в который они были вставлены, был изменен путем выбора генотипов, в которых избыточные ассимиляты были перенесены в колос, где они позволили продуцировать большее количество зерновок при равном количестве колосков. Уменьшение высоты также позволило увеличить использование азотного удобрения и, следовательно, производство биомассы без полегания (Porceddu, Blanco, 2014).

\section{Генетическая устойчивость к болезням}

Изменение климата приводит к серьезным изменениям в микробных системах почв, возникновению и распределению сорняков, насекомых и болезней (Easterling et al., 2007). Наиболее распространенная позиция селекционеров в отношении генетической устойчивости создаваемых сортов заключается в том, чтобы отдавать предпочтение низким уровням длительной устойчивости, основанным на нескольких генах, вместо высокого уровня устойчивости, контролируемого отдельными генами, несмотря на широкую генетическую изменчивость, присутствующую в сортах и диких популяциях родственных видов (Porceddu, Blanco, 2014).

Самые большие потери вызывает стеблевая ржавчина (Puсcinia graminis f. ssp. tritici). Для борьбы с расами патогена, существующими в Италии, селекционеры использовали устойчивые сорта из Северной Дакоты (Yuma, Ld 390, Lakota и Wells) и образцы полбы (T. dicoccum) (Bozzini, 1966; Zitelli, 1968).

Для преодоления поражения листовой ржавчиной (Puccinia recondita) были получены линии Giorgio и Gerardo (Zitelli, 1973), которые использовались селекционерами для дальнейшей работы.

Первым источником фактора устойчивости к мучнистой росе (Blumeria graminis) был американский сорт Yuma, в родословную которого входят устойчивые сорта T. dicoccum Vernal и Khapli (Bozzini, 1966; Zitelli, Vallega, 1968).

Позднее многие гены устойчивости к ржавчине, мучнистой росе и фузариозу были идентифицированы у родственных видов и введены в твердую пшеницу (Ceoloni et al., 2014). Исследуя высокий уровень устойчивости к листовой ржавчине итальянского сорта Creso, авторы пришли к выводу, что ген Lr14 можно рассматривать как важный ген устойчивости, который в настоящее время используется селекционерами в средиземноморских районах (Marone et al., 2009; Maccaferri et al., 2010).

Фузариоз колоса (Fusarium head blight, FHB), вызванный Fusarium graminearum, является одним из наиболее существенных заболеваний пшеницы в мире, приводящим к потере урожая и загрязнению микотоксинами. Для борьбы с этой болезнью сотрудниками итальянских университетов Туссии (Università della Tuscia, Viterbo), Падуи (Università degli Studi di Padova), Болоньи (University of Bologna), Национального исследовательского совета в Парме, Университета Британской Колумбии в Канаде (University of British Columbia) и Бейлорского медицинского колледжа (Baylor College of Medicine) в США были проведены совместные работы по созданию трансгенных растений пшеницы, которые были бы наделены новыми способностями к ингибированию, коррелирующему со значительной задержкой симптомов, вызванных фузариозом (Ferrari et al., 2012; Moscetti et al., 2013).

В Италии широко распространен переносимый почвой вирус злаковой мозаики (CSBMV), где он часто вызывает снижение урожайности восприимчивых сортов пшеницы на 50-70 \%. Уче- ными Болонского университета были проведены исследования сравнения реакций на вирус мозаики у 89 сортов твердой пшеницы в течение семи сезонов за период с 1995 по 2005 г. в поле возле Болоньи с естественными источниками инокулята CSBMV (Vallega et al., 2009). Результаты исследования показали, что большинство итальянских коммерческих сортов твердой пшеницы довольно восприимчивы к CSBMV, и ни один из них не был признан полностью устойчивым. Такое же наблюдение было сделано для большого количества сортов твердой пшеницы из других стран. Основная часть немногих идентифицированных сортов с высокой устойчивостью к CSBMV получена из сорта Edmore (США), и поэтому разумным предположением является то, что Edmore и его устойчивые к CSBMV производные несут основной ген устойчивости к CSBMV или блок генов. Чтобы проверить эту гипотезу, в течение 2007-2008 гг. в поле с естественными источниками инокулята CSBMV было выращено 160 рекомбинантных инбредных линий поколения F8 (RIL F8), полученных от скрещивания coртов Neodur (Франция) (устойчивый сорт, выведенный на основе Edmore) и Cirillo (Италия) (высокочувствительный). Авторы пришли к выводу, что сорт Neodur внес по крайней мере три, возможно, связанных основных гена. Исследование дало доказательство наличия значительного темпа изменения относительной степени устойчивости линий с точки зрения выраженности симптомов. В настоящее время популяция Neodur / Cirillo профилируется для идентификации QTL, ассоциированного с его специфическими генами устойчивости к CSBMV, и для выяснения природы генов, вызывающих временное изменение устойчивости, и того, что порождает искажение модели наследования.

\section{Засухоустойчивость}

Среди ряда абиотических и биотических факторов, снижающих продуктивность и стабильность производства сельскохозяйственных культур, засуха считается одним из наиболее важных (Borlaug, Dowswell, 2005). Быстрое расширение ирригационного и несельскохозяйственного использования воды в сочетании с угрожающим сокращением запасов пресной воды и растущими расходами усиливают потенциал для конфликтов между различными категориями пользователей и между странами (Tuberosa et al., 2007). Основные элементы глобального изменения климата повышение температуры и концентрации $\mathrm{CO}_{2}$, изменения в возникновении болезней и почвенных микробов - будут влиять на посевные площади пшеницы во всем мире. Главной проблемой для селекционеров пшеницы на этом этапе является выбор генотипов, способных переносить тепловой стресс и дефицит воды. Перед ними стоит задача создать сорта, которые могут оптимально использовать воду в более влажные годы в сочетании с устойчивостью к засухе в течение многих лет, которые не имеют оптимального уровня осадков. Возможность такого сочетания была представлена A. Blum (2005) в его обзоре по селекции на засухоустойчивость. Основой для анализа явились достижения СІММYТ, где созданы сорта, которые сочетают в себе высокий урожайный потенциал в благоприятных условиях с толерантностью к менее благоприятным условиям засухи или дефицита воды. Глобальная программа пшеницы СІММYТ подчеркивает важность создания сортов пшеницы со стабильными урожаями в широком диапазоне сред. Такие сорта, идентифицированные путем тестирования партнерами Национальных сельскохозяйственных исследовательских систем (National Agricultural Research Systems, NARS) в Международной сети улучшения качества пшеницы, образуют ге- 
нетическую основу для дальнейшего повышения толерантности к стрессу и засухе. Лучшее понимание биохимических процессов и физиологических механизмов, позволяющих сельскохозяйственным культурам справляться с негативными последствиями нехватки воды, является важной предпосылкой для селекционной деятельности (Bingham, McCabe, 2006). При выборе устойчивых линий селекционеры опираются на ряд морфологических и физиологических показателей, таких как форма устьиц, их размеры и количество на единицу площади листа, водный потенциал листа, способность к осмотической адаптации, относительное содержание влаги, накопление осмолитов и абсцизовой кислоты, которая тормозит ростовые и метаболические процессы, подавляет транспирацию (Tuberosa, Salvi, 2002; Cattivelli et al., 2008; Tuberosa, 2012). Фенотипирование продолжает представлять собой ключевой шаг в понимании стрессоустойчивости в молекулярную эпоху (Porceddu, Blanco, 2014). На уровне сельскохозяйственных культур эмпирическая селекция в условиях дефицита воды была успешной и остается самым важным путем для увеличения урожайности и водопользования (Condon et al., 2004).

На рабочем совещании WUEMED (Water Use Efficiency in MEDiterranean Agriculture) в Риме в сентябре 2005 г. были определены основные факторы, нацеленные на производство более засухоустойчивых сортов: ранний активный рост для улучшения посевов и уменьшения испарения почвы; корневая архитектура и размер для оптимизации сбора воды и питательных веществ в соответствии с условиями, преобладающими в данной среде; ингибирование побега для увеличения его выживаемости и накопления углеводов в стеблях для обеспечения налива зерна (Tuberosa et al., 2007). По итогам рабочего совещания были сделаны акценты на схемы, которые объединяют традиционные подходы к отбору с результатами исследований по выявлению признаков, ограничивающих урожай в условиях дефицита воды (Araus et al., 2002, 2003); на определение генетической основы этих признаков посредством картирования QTL и их клонирования (Salvi, Tuberosa, 2005); на модели, способные интегрировать информацию, полученную при исследовании культур на молекулярном, клеточном, физиологическом, эволюционном, агрономическом и других уровнях, и их способность реагировать на изменение условий окружающей среды (Tardieu, 2003). Так, J.L. Araus и его коллеги (2002), говоря о физиологических особенностях, которые способствуют повышению продуктивности в условиях умеренной засухи, выделяют такие факторы, как улучшение эффективности водопользования и индекс урожайности. Клонирование генов открыло новые перспективы в выяснении механизмов растений, вызванных стрессом. Особенно интересными в этом вопросе являются результаты, связанные с экспрессией последовательностей и мРНК в сортах твердой пшеницы Capeiti и Creso, протестированных при различных уровнях водного стресса на стадии снижения (Cattivelli et al., 2002). Геномная карта основных локусов и QTL, влияющих на стрессоустойчивость, определила решающую роль хромосом группы 5, где была обнаружена самая высокая концентрация QTL и основных локусов, контролирующих адаптацию растения к окружающей среде (Tuberosa et al., 2002). Обширные молекулярные исследования привели к клонированию многих связанных со стрессом генов и чувствительных элементов. Было показано, что экспрессия некоторых генов, связанных со стрессом, сопряжена со стрессоустойчивыми QTL, что позволяет предположить, что эти гены могут представлять молекулярную основу стрессоустойчи- вости (Aprile et al., 2013). Иная стратегия реагирования на стресс была обнаружена у двух сортов твердой пшеницы, характеризующихся различной эффективностью водопользования, подверженных засухе, жаре и сочетанию обоих стрессов. Сорт Ofanto (более низкая эффективность водопользования) в условиях засухи активировал большой набор хорошо известных генов, связанных с засухой, в то время как Cappelli (более высокая эффективность водопользования) показал конститутивную экспрессию нескольких генов, вызванных засухой в Ofanto, и модуляцию ограниченного числа генов в ответ на стресс (Rampino et al., 2012). R. Tuberosa и S. Salvi (2006) представили обзор подходов, основанных на геномике, для повышения засухоустойчивости сельскохозяйственных культур. Обращает на себя внимание публикация D. Sehgal и R. Yadav (2010), где основное внимание уделяется точности выбора морфофизиологических признаков для определения засухоустойчивости и представлен обзор о молекулярных маркерах, которые могут быть использованы для повышения эффективности селекции по этим признакам в селекционных программах.

\section{Качество зерна и макаронных изделий}

В производстве макаронных изделий в Италии в основном используется зерно твердой пшеницы, а качество макаронных изделий всегда было одной из важнейших целей селекции. Технологическое качество крупки из твердой пшеницы (semolina) стало одной из целей исследований по генетическим и биохимическим улучшениям для производства макаронных изделий, а в последнее время - и по улучшению хлебопекарных качеств. Только на Сицилии более 50 видов традиционных сортов хлеба из твердой пшеницы были классифицированы в Атласе сицилийского хлеба (Atlante del pane di Sicilia). Проект Атласа был осуществлен исследовательским консорциумом «Gian Pietro Ballatore» (L'Atlante del pane di Sicilia (1999-2001), 2019). В средиземноморских районах использование сортов твердой пшеницы для производства хлеба постоянно растет из-за его вкусовых качеств и длительного срока хранения по сравнению с хлебом, полученным из мягкой пшеницы (Pogna et al., 1996, 2002). Процесс производства итальянского хлеба из твердой пшеницы, в основном ремесленного характера, укоренившегося со временем, варьируется от одного района к другому, что приводит к широкому ассортименту продуктов. Многие из них получили признание качества на национальном уровне. Кроме того, три вида хлеба были отмечены европейскими знаками: «Pane di Altamura» и «Pagnotta del Dittaino» были признаны «Защищенным обозначением происхождения» ("Protected Designation of Origin" - PDO), a «Pane di Matera» - как «Защищенный географическим указанием» ("Protected Geographical Indication" - PGI) (Pasqualone, 2012).

U. De Cillis (1942) был первым, кто показал, что из макаронных изделий, произведенных с использованием стекловидных зерен и содержащих больше белка, получается продукт лучшего качества. Позже к тем же выводам пришли многие другие ученые, которые также показали существование постоянной взаимосвязи между свойствами и содержанием глютена и качеством пасты (теста) (Novaro et al., 1993; Mariani et al., 1995; Autran, Galterio, 1989; D’Egidio et al., 1990). Эти работы способствовали активизации итальянских ученых в исследовании состава белка зерна, содержания белка в зерне и цвета зерна с использованием различных подходов.

Качество макаронных изделий сильно зависит от количества и качества клейковины в составе белка зерна. Глютен (gluten) - английское наименование клейковины, а клебер (kleber) - немецкое. Глютен представляет собой протеиновый комплекс, состоя- 
щий из компонентов глиадина и глютенина, первый делает массу глютена растяжимой и эластичной, второй - прочной. Концентрация белка зерна - самый важный индекс качества семолины для получения пасты (D'Egidio et al., 1990). При оценке качества зерна необходимо учитывать два фактора: количество белка и качество глютена. Первый определяется средой, в которой растение растет и достигает зрелости. Если влажности, инсоляции или удобрения недостаточно, зерно рискует не достичь надлежащего качества и, следовательно, иметь низкую протеиновую ценность. Второе связано с сортом: современная пшеница durum вырабатывает более стойкий глютен, в то время как глютен старых сортов менее стойкий. Также чрезмерное использование химических продуктов, таких как глифосфат для высушивания зерна перед сбором урожая в Канаде, транспортировка за тысячи километров и длительное хранение в неидеальных условиях, могут поставить под угрозу качество.

Поскольку глютен состоит из полипептидов, контролируемых отдельными кодоминантными факторами, особое внимание было уделено анализу этих генов. Было проведено много исследований аллельной изменчивости локусов Gli и Glu и взаимосвязей с технологическим качеством (Dal Belin Peruffo et al., 1982; Porceddu et al., 1983; Laiandra et al., 1987, 1990). Было показано, что компоненты глиадинов кодируются генами Gli-1, расположенными на коротких плечах гомеологичных хромосом групп 1 и 6 (Laiandra et al., 1984); локусы для низкомолекулярных (LMW) субъединиц глютенина (Glu-3) расположены на коротких плечах хромосом группы 1, тесно сцепленных c Gli-1 (Pogna et al., 1990); существует огромное количество генетических вариаций для субъединиц глиадина и глютенина, как в культивируемой пшенице, так и в диких сородичах (Ciaffi et al., 1992), что дает возможность выбора. В генетических и селекционных программах университета Витербо, направленных на улучшение качества глютена, комплексные локусы, контролирующие субъединицы глиадина и глютенина, и последующее воздействие на качество глютена также изучались с использованием методов молекулярных маркеров. Гомологичные гены, кодирующие протеиндисульфидизомеразу (PDI) - важный фермент, участвующий в образовании дисульфидных связей и влияющий на их промоторы и качество, были клонированы и охарактеризованы (Ciaffi et al., 2006). A. Blanko и его коллеги (2002) использовали молекулярные и морфологические маркеры для обнаружения и сравнения в различных средах значимости QTL, участвующих в выражении сложных признаков, таких как содержание белка зерна, объем седиментации, цвет семолины и урожай зерна. Был сделан вывод, что количество QTL, которые влияют на признак, не может быть правильно оценено в одной среде. Более того, поскольку успех каждой селекционной программы во многом зависит от эффективности селекции, был предложен и применен ряд методов для оценки новых генотипов твердой пшеницы. В качестве альтернативы скрещиванию мощным инструментом для производства новых линий может быть трансгенная технология. В настоящее время технология рекомбинантных ДНК предоставляет передовые средства для идентификации и выделения генов, кодирующих специфические характеристики в определенном организме, и для передачи копий этих генов в совершенно другой организм. Технология рекомбинантных ДНК была применена также в твердой пшенице для производства новых линий без использования классических методологий скрещивания и отбора. Сотрудничество между Научно-исследовательским институтом зерновых культур (Foggia) и Отделом сельскохозяйственных наук Бристольского университета (Великобритания) позволило оптимизировать метод трансформации твердой пшеницы (вид, хорошо известный как непокорный для трансформации) и получить растения сорта Ofanto, трансформированные для субъединиц глютенина (Terzi et al., 2005).

Содержание белка и другие качественные параметры зерна твердой пшеницы являются полигенными признаками, на которые сильно влияют факторы окружающей среды. Их оценка и получение улучшенных линий дорогостоящи, трудоемки из-за низкой наследуемости и сложных биологических основ. По этим причинам селекционеры ищут альтернативные стратегии, более быстрые и надежные. Картирование QTL позволяет идентифицировать ассоциированные молекулярные маркеры, которые можно использовать при вспомогательном отборе и, следовательно, выполнять генотипический отбор в альтернативе традиционному фенотипическому отбору. У твердой пшеницы сегрегация популяции рекомбинантных инбредных линий была получена путем скрещивания с сортом Messapia (низкое содержание белка) и диким тетраплоидом T. dicoccoides (высокое содержание белка). Для этой популяции была составлена молекулярная карта, которая в настоящее время содержит 458 маркеров, включающих комплекс морфологических, биохимических, RFLP, AFLP и микросателлитных маркеров (Blanco et al., 1998, 2004).

Среди других параметров, влияющих на качество макаронных изделий, желтый цвет является характеристикой, которая хотя и имела второстепенное значение в прошлом, в настоящее время приобретает все большее значение и в Италии. Только недавно итальянские селекционеры начали серьезно рассматривать проблему содержания пигмента. Желтый цвет макаронных изделий определяется содержанием каротиноидов и активностью липоксигеназы, причем оба эти признака контролируются несколькими основными генами с аддитивными эффектами и значительно зависят от условий окружающей среды. Значительное увеличение содержания каротиноидов было получено с помощью хромосомной инженерии с интрогрессией в твердую пшеницу гена Yp (желтый пигмент) из Agropyron elongatum (Ceoloni et al., 2005). Генетическая изменчивость компонентов ҮРС (концентрация желтого пигмента) и каротиноидов была проанализирована в 102 образцах дикой и культурной тетраплоидной пшеницы (Digesù et al., 2009). В целом, современные сорта показали значительно более высокие значения YPC по сравнению со старыми сортами и образцами T. dicoccum и T. dicoccoides. Значение YPC или 4.2 ррт считается минимальным количеством для того, чтобы получить макароны приемлемого цвета. Большинство современных французских сортов и некоторые итальянские, такие как Grecale и Svevo, превышают это значение. Общее содержание каротиноидов имеет полигенный характер с высокой наследуемостью. Выделены клоны библиотеки ВАС, содержащие гены, кодирующие три различных фермента в биосинтезе каротиноидов: фитосинтаза (PSY), фитоендесатураза (PDS) и каротиндесатураза (ZDS) (Cenci et al., 2004).

Если рассматривать стратегию улучшения основных факторов, влияющих на качество твердой пшеницы, то селекция с помощью молекулярных маркеров для идентификации генотипов твердой пшеницы, имеющих QTL, коррелирующих в пространстве и времени с признаками урожайности и качества, может быть интересной задачей для ускорения идентификации необходимых генотипов (Scarascia Mugnozza, 2005). 


\section{Заключение}

Селекция твердой пшеницы в Италии, направленная на создание новых сортов, выгодных изготовителю самой потребляемой продукции в стране, - процесс безостановочный. Сегодня он требует новых подходов и методов, которые должны помочь ускорить создание высокопродуктивных и высококачественных сортов. Все исследовательские центры, университеты и крупные корпорации, которые в последнее время в основном и создают новые сорта, занимаются изучением и использованием достижений геномной селекции (GS) и, следовательно, пополнением знаний о геноме твердой пшеницы.

В рамках международного проекта Пшеничная инициатива (Wheat Initiative, 2019), координатора глобальных исследований пшеницы, в 2013 г. была создана экспертная рабочая группа по геномике и селекции твердой пшеницы (The Expert Working Group on Durum Wheat Genomics and Breeding). Предложение о создании экспертной группы было представлено Луиджи Каттивелли (Luigi Cattivelli, Agricultural Research Council (CRA), Italy) и Роберто Тубероза (Roberto Tuberosa, University of Bologna, Italy), которые сегодня являются ее сопредседателями. Цель - собрать и объединить деятельность тех, кто заинтересован в продвижении конкретных исследовательских мероприятий, направленных на повышение продуктивности и качества твердой пшеницы, а также сотрудничество с научным сообществом, занимающимся геномикой хлебной пшеницы. Экспертная группа два раза в год проводит встречи своих членов с представлением отчетов о работе в форме докладов на ту или иную актуальную тему. В частности, в 2019 г. в Болонье проведен тренинг-курс «Геномная селекция пшеницы» (Genomics-assisted breeding of wheat), основная цель которого - преобразовать передовую геномную информацию в практическую селекцию с помощью геномики. Любой специалист из любой страны, желающий принять участие в работе экспертной группы по геномике и селекции твердой пшеницы, может стать ее членом (Wheat Initiative. The Expert Working Group on Durum Wheat Genomics and Breeding, 2019).

\section{Список литературы / References}

Ляпунова О.А. Средиземноморские староместные сорта твердой пшеницы, сохраняемые В коллекции ВИР. Труды по прикладной ботанике, генетике и селекции. 2018;179:3:68-84. DOI: 10.30901/22278834-2018-3-68-8.

[Lyapunova O.A. Mediterranean landraces of durum wheat preservedin the Vavilov collection (VIR). Trudy po Prikladnoy Botanike, Genetike $i$ Selektsii = Proceedings on Applied Botany, Genetics and Breeding. 2018;179:3:68-84. DOI: 10.30901/2227-8834-2018-3-68-8. (in Russian)]

Alessandroni A., Rusmini B., Scalfati M.C. Influenza di specie del genere Triticum e di altri generi nelle discendenze di incroci interspecifici e intergenerici per il miglioramento genetico di Triticum durum. Ist. Naz. Cerealicoltura (Roma). 1966;88bis:1-26.

Aprile A., Havlickova L., Panna R., Marè C., Borrelli G.M., Marone D., Perrotta C., Rampino P., De Bellis L., Curn V., Mastrangelo A.M., Rizza F., Cattivelli L. Different stress responsive strategies to drought and heat in two durum wheat cultivars with contrasting water use eficiency. BMC. Genomics. 2013;14:821.

Apsovsementi S.p.A., 2019. available at http://www.apsovsementi.com/it/.

Apsovsementi varieties catalog, 2019. available at http://www.apsovsementi. com/it/catalogo/.

Araus J.L., Slafer G.A., Reynolds M.P., Royo C. Plantbreeding and water relations in C3 cereals: what should we breed for? Ann. Bot. 2002;89:925-940.

Araus J.L., Bort J., Steduto P., Villegas D., Royo C. Breeding cereals for Mediterranean conditions: ecophysiological clues for biotechnology application. Ann. Appl. Biol. 2003;142:129-141.

Autran J.C., Galterio G. Associations between electrophoretic composition of protein, quality characteristics and agronomical attributes of durum wheats. II. Protein-quality associations. J. Cereal Sci. 1989;9:195-215.
Bagnara D., Scarascia Mugnozza G.T. Outlook in breeding for yield in durum wheat: Scarascia Mugnozza G.T. (ed). Proceedings of the Symposium of Genetics and Breeding of durum wheat. Bari, Italy, May 14-18, 1973;249-274.

Ballatore G.P. Due nuove cultivar di grano duro. Inf. Agr. 1970;38:2963-2966.

Barbieri A., Deidda M. Contributo al miglioramento genetico del grano duro. Sementi Elette. 1968;3:1-3.

Bianchi A. Nazareno Strampelli: wheat breeder extraordinaire and father of Italy's 'Green revolution'. Diversity. 1995;11:135-136.

Bingham I.J., McCabe V.B. Commercially available plant growth regulators and promoters modify bulk tissue abscisic acid concentrations in spring barley, but not root growth and yield response to drought. Ann. Appl. Biol. 2006;149:291-304. DOI: 10.1111/j.1744-7348.2006.00093.x.

Blanco A., Bellomo M.P., Cenci M.P., De Giovanni C., D'Ovidio R., lacono E., Laddomada B., Pagnotta M.A., Porceddu E., Sciancalepore A., Simeone R., Tanzarella O.A. A genetic linkage map of durum wheat. Theor. Appl. Genet. 1998;97:721-728.

Blanco A., De Pace C., Porceddu E., Scarascia Mugnozza G.T. Genetics and breeding of durum wheat in Europe: Fabiani G., Lintas C. (eds). Durum wheat: chemistry and technology, AACC, St. Paul, MN, USA. 1988;17-45.

Blanco A., Pasqualone A., Troccoli A., Di Fonzo N., Simeone R. Detection of grain protein content QTLs across environments in tetraploid wheats. Plant Mol. Biol. 2002;48(5-6):615-623. DOI: 10.1023/A:1014864230933.

Blanco A., Simeone R., Cenci A., Gadaleta A., Tanzarella O.A., Porceddu E., Salvi S., Tuberosa R., Figliuolo G., Spagnoletti P., Roder M., Korzun V. Extention of the "Messapia $\times$ dicoccoides" linkage map of Triticum turgidum (L.) Thell. Cell. Mol. Biol. Lett. 2004;9(3):529-541.

Blum A. Drought resistance, water-use efficiency, and yield potential - are they compatible, dissonant, or mutually exclusive? Aust. J. Agric. Res. 2005;56:1159-1168. DOI: 10.1071/AR05069.

Boggini G., Cattaneo M., Corbellini M., Perenzin M., Brandolini A., Vaccino P. Le varietà di frumento tenero costituite da Nazareno Strimpelli: descrizione morfologica, agronomica, biochimica, molecolare e tecnologica. Rivisitazione scientifica di una pagina di storia italiana. 2004.

Bogyo T.P., Scarascia Mugnozza G.T., Sigurljornsson B., Bagnara D., Bozzini A. Durum wheat yield performance nurseries. Proceedings of the Fourth FAO/ Rockefeller Foundation Wheat Seminar, Tehran, Iran, May 21-June 2, 1973. FAO, Rome, Italy. 1974;26-35.

Borlaug N.E., Dowswell C.R. Feeding a world of tenbillion people: a 21st century challenge: Tuberosa R., Phillips R.L., Gale M. (eds). Proceedings of 'In the Wake of the Double Helix: From the Green Revolution to the Gene Revolution', 27-31 May 2003. Bologna, Italy. 2005;3-24.

Borojevic K. Art and science of Italian wheat breeding and its influence on breeding in South and Central Europe: Pogna N.E., Romano M., Pogna A.E., Galterio G. (eds). Proceedings of the Tenth International Wheat Symposium, Paestum, Italy 2003. Rome: Istituto Sperimentale per Cerealicoltura. 2003;109-113.

Borojevic K., Borojevic K. Historic role of the wheat variety Akakomugi in Southern and Central European wheat breeding programs. Breed. Science. 2005a;55(3):253-256. DOI: 10.1270/jsbbs.55.253.

Borojevic K., Borojevic K. The transfer and history of 'reduced height genes' (Rht) in wheat from Japan to Europe. J. Heredity. 2005b;96(4):455-459. DOI: 10.1093/jhered/esi060.

Boyacioglu H. Global durum wheat use trending upward. October 11, 2017. World-grain.com. available at https://www.world-grain.com/articles/8777global-durum-wheat-use-trending-upward.

Bozzini A. Eredità della resistenza all'oidio in incroci tra frumenti tetraploidi. Genet. Agrar. 1966; 20:249-254.

Bozzini A. Origin, distribution and production of durum wheat in the world: Fabiani G., Lintas C. (eds). Durum wheat: chemistry and technology. AACC, St. Paul, MN, USA. 1988;1-16.

Bozzini A., Bagnara D. Creso, Tito, Mida, new durum wheats from CNEN Agricultural Laboratory. Inf. Agr. 1974;20:1-6.

Bozzini A., Scarascia Mugnozza G.T. A dominant short straw mutation induced by thermal neutrons in durum wheat. Wheat Inf. Serv. 1967;23-34, 5-6.

Braun H.-J., Altay F., Kronstand W.E., Beniwal S.P.S., McNab A. Wheat: prospects for global improvement. Proceedings of the 5th International Wheat Conference Ankara, Turkey, 10-14 June 1996. Developments in Plant Breeding, Berlin: Springer. 1997;6:582 pages.

Bressanini D. Il Senatore Cappelli e gli altri grani di Nazareno Strampelli. Marzo 2010. Le Scienze. Edizione italiana di Scientific American. available on line at http://bressanini-lescienze.blogautore.espresso.repubblica.it/2010/03/22/ il-senatore-cappelli-e-gli-altri-grani-di-nazareno-strampelli.

Capone L. Nazareno Strampelli, il genetista che piantava i semi dell'innovazione. II Foglio quotidiano. Maggio 2016. available on line at https://www. 
ilfoglio.it/scienza/2016/05/30/news/nazareno-strampelli-il-genetista-chepiantava-i-semi-dellinnovazione-96692.

Casale F. Tre novità agrarie. Genet. Agrar. 1955;5:339-350.

Cattivelli L., Baldi P., Crosatti C., Di Fonzo N., Faccioli P., Grossi M., Mastrangelo A.M., Pecchioni N., Stanca M. Chromosome regions and stress-related sequences involved in resistance to abiotic stress in Triticeae. Plant Mol. Biol. 2002:48:649-665.

Cattivelli L., Rizza F., Badeck F.W., Mazzucotelli E., Mastrangelo A.M., Francia E., Marè C., Tondelli A., Stanca A.M. Drought tolerance improvement in crop plants: An integrated view from breeding to genomics. Field Crop. Res. 2008;105(1-2):1-14. DOI: 10.1016/j.fcr.2007.07.004.

Ceoloni C., Kuzmanovic L., Forte P., Gennaro A., Bitti A. Targeted exploitation of gene pools of alien Triticeae species for sustainable and multi-faceted improvement of the durum wheat crop. Crop Past Sci. 2014;65(1):96-111. DOI: 10.1071/CP13335.

Ceoloni C.M., Pasquini M., Simeone R. The cytogenetic contribution to the analysis and manipulation of the durum wheat genome: Royo C., Nachit M.N., Di Fonzo N., Araus J.L., Pfeiffer W.H., Slafer G.A. (eds). Durum wheat breeding: current approaches and future strategies. Haworth Press, New York, USA. 2005.

Cenci A., Somma S., Chantret N., Dubcovsky J., Blanco A. PCR identiication of durum wheat $B A C$ clones containing genes coding for carotenoid biosynthesis enzymes and their chromosome localization. Genome. 2004;47;911-917.

Centri di Ricerca CREA, 2019. available at https://www.crea.gov.it/it/centridi-ricerca.

Ciaffi M., Dominici L., Laiandra D., Porceddu E. Seed storage proteins of wild wheat progenitors and their relationships with technological properties. Hereditas. 1992;116(3):315-322.

Ciaffi M., Paolacci A.R., D'Aloisio E., Tanzarella O.A., Porceddu E. Cloning and characterization of wheat PDI (protein disulide isomerase) homoeologous genes and promoter sequences. Gene. 2006;366(2):209-218. DOI: 10.1016/j. gene.2005.07.032.

Condon G., Richards R.A., Rebetzke G.J., Farquhar G.D. Breeding for high wateruse efficiency. J. Exp. Bot. 2004;55:2447-2460. DOI: 10.1093/jxb/erh277.

Conti G. II problema granario appulo-lucano. Risultati di un ventennio di selezione. Annali di Sperimentazione Agricola. 1948;Nuova Serie 2:317-354.

D'Amato F. The progress of Italian wheat production in the first half of the 20th Century; the contribution of breeders. Agric. Med. 1989;119:157-174.

D'Amato F. Induced mutations in crop improvement: basic and applied aspects. Agric. Med. 1992;122:31-60.

D’Egidio M.G., Fortini S., Galterio G., Mariani B.M., Sgrulletta D., Volpi M. Protein content and composition of Italian durum wheat semolina: correlations with spaghetti cooking quality. Qualitas Plantarum. Plant Foods Hum. Nutr. 1979;28(4):333-348.

D'Egidio M.G., Mariani B.M., Nardi S., Novaro P., Cubadda R. Chemical and technological variables and their relationships: a predictive equations for pasta cooking quality. Cereal Chem. 1990;67:275-281.

Dal Belin Peruffo A., Pallavicini C., Pintor R., Pogna N.E. Analysis of wheat varieties by gliadin electrophoregrams. III. Catalogue of electrophoregram formulas of 22 Italian durum wheat varieties. Genet. Agr. 1982;36:365-374.

De Cillis U. I frumenti siciliani. Stazione Sperimentale di Granicoltura per la Sicilia, Catania. 1942;1-323

De Cillis U. Le finalita che si richiedono al miglioramento genetico del frumento duro ed i mezzi per raggiungerle. Genet. Agr. 1964;18:51-70.

De Pace C., Snidaro D., Ciaffi M., Vittori D., Ciofo A., Qualset C., Scarascia Mugnozza G.T. Introgression of Dasypyrum villosum chromatin into common wheat improves grain protein quality. Euphytica. 2001;117:67-75.

Defez R., Salvi S. La "magia della scienza" non è stregoneria: più Strampelli, meno Steiner. Biodinamica in università, Harry Potter sale in cattedra. I Foglio quotidiano. Novembre 2016. available on line at https://www.lfoglio.it/scienza/2016/11/20/news/agricoltura-biodinamica-strampelli-steiner-107079.

Deidda M., Motzo R., Giunta F., Fois S. Evoluzione varietale e qualità in frumento duro (Triticum turgidum ssp. durum): dalle vecchie popolazioni alle attuali cultivar. available at www.anisn.it - Università degli Studi di Sassari - Facoltà di Agraria: Dipartimento di Scienze agronomiche e Genetica vegetale agraria, 18 dicembre 2001;1-30.

Digesù A.M., Platani C., Cattivelli L., Mangini G., Blanco A. Genetic variability in yellow pigment components in cultivated and wild tetraploid wheats. J. Cereal Sci. 2009;50(2);210-218. DOI: 10.1016/j.jcs.2009.05.002.

Dionigi A. Informazioni sperimentali del triennio 1969-71 sul nuovo grano duro precocissimo "ISA uno". Annali ISA. 1971;2:335-353.
Easterling W.E., Aggarwal P.K., Batima P., Brander K.M., Erda L., Howden S.M., Kirilenko A., Morton J., Soussana J.-F., Schmidhuber J., Tubiello F.N. Food, fibre and forest products: Parry M.L. et al. (eds). Proceedings Climate Change 2007: Impacts, Adaptation and Vulnerability. Contribution of WG II to the Fourth Assessment Report of the IPCC. Cambridge University Press, UK. 2007;273-313.

Fazio L. The pasta is 'made in Italy.' The wheat isn't. II manifesto, Italy, Rome, 2017. available at https://global.ilmanifesto.it/the-pasta-is-made-in-italythe-wheat-isnt.

Ferrari S., Sella L., Janni M., De Lorenzo G., Favaron F., D'Ovidio R. Transgenic expression of polygalacturonase-inhibiting proteins in Arabidopsis and wheat increases resistance to the lower pathogen Fusarium graminearum. Plant Biol. 2012;14(s1):31-38. ISSN: 1438-8677.

Forlani R. II frumento: monografia di genetica agraria. Pavia, Italy. 1945;1-128.

Giorgi B. Le due rivoluzioni verdi del XX secolo: i protagonisti, i luoghi, i tem$\mathrm{pi}$, i grani impiegati, i risultati - un piccolo omaggio a due grandi benefattori dell'umanità, Nazareno Strampelli e Norman Borlaug. CERMIS, Centro ricerche e Sperimentazione per il Miglioramento Vegetale "N. Strampelli". 2014.

Giorgi D., D'Ovidio R., Tanzarella O.A., Ceoloni C., Porceddu E. Isolation and characterisation of $\mathrm{S}$ genome specific sequences from Aegilops species of the Sitopsis section. Genome. 2003;46(3):478-489. DOI: 10.1139/g03-022.

Grifoni R. Appulo: nuovo grano duro precoce. Terra Pugliese. 1964;13:1.

Italy: Wheat and durum. Bi-weekly bulletin. December 19, 2003;16(22).

L'Atlante del pane di Sicilia (1999-2001), 2019. available at http://www.ilgranoduro.it/ documenti/atlante-del-pane.pdf.

Laiandra D., Benedettelli S., Margotta B., Spagnoletti-Zeuli P.L., Porceddu E. Seed storage proteins and wheat genetic resources: Srivastava J.P., Damania A.B. (eds). Proceedings of Wheat genetic resources: meeting diverse needs, Aleppo, Syria. 1990;73-87.

Laiandra D., Colaprico G., Kasarda D.D., Porceddu E. Null alleles of gliadin blocks in bread and durum wheat cultivars. Theor. Appl. Genet. 1987;74:610-616.

Laiandra D., Kasarda D.D., Morris R. Chromosomal assignment of gene coding for the wheat gliadin protein components of the cultivar Cheyenne and Chinese Spring by two dimensional electrophoresis. Theor. Appl. Genet. 1984;68:531-539.

Lorenzetti R. La scienza del grano. L'esperienza scientifica di Nazareno Strampelli e la granicoltura italiana dal periodo giolittiano al secondo dopoguerra. Roma, Ministero per i beni e le attività culturali. 2000a;1-377.

Lorenzetti R. The Wheat Science: The Green Revolution of Nazareno Strampelli. J. Genet. Breed. 2000b;1-230.

Lotti C., Salvi S., Pasqualone A., Tuberosa R., Blanco A. Integration of AFLP markers into and RFLP-based map of durum wheat. Plant Breed. 2000;119:1-10. DOI: 10.1046/j.1439-0523.2000.00526.x.

Lusiani M. L'incredibile storia dell'inventore del grano Cappelli. Amore Nerra Magazine, 2015. available at https://www.amoreterra.com/magazine/it-IT.

Lusiani M. Che cosa sono i grani antichi. Amore Nerra Magazine 19.01.2017. available at https://www.amoreterra.com/magazine/it-IT.

Maccaferri M., Sanguineti M.C., Donini P., Tuberosa R. Microsatellite analysis reveals a progressive widening of the genetic basis in the elite durum wheat germplasm. Theor. Appl. Genet. 2003;107(5):783-797. DOI: 10.1007/s00122003-1319-8.

Maccaferri M., Sanguineti M.C., Mantovani P., Demontis A., Massi A., Ammar K., Kolmer J.A., Czembor J.H., Ezrati S., Tuberosa R. Association mapping of leaf rust response in durum wheat. Mol. Breed. 2010;26(2):189-228. DOI: 10.1007/s11032-009-9353-0.

Maccaferri M., Sanguineti M.C., Tuberosa R. Analysis of linkage disequilibrium in a collection of elite durum wheat genotypes. Mol. Breed. 2005;15:271289. DOI: 10.1007/s11032-004-7012-z.

Maliani C. Importance du blé dur et son amélioration génétique par le moyen du croisement interspécifique. Melhoramento. 1968;21:28-33.

Maliani C. Nuove varietà di grano duro e loro caratteristiche. Quaderni Accademia Georgofili VI. 1998;57-64.

Mariani B.M., D'Egidio M.G., Novaro P. Durum wheat quality evaluation: influence of genotype and environment. Cereal Chem. 1995;72:194-197.

Mariani L. Nazareno Strampelli e il suo tempo di (con un commento di Alberto Guidorzi). Note a margine del convegno "Storia e attualità di Nazareno Strampelli" del 6 giugno 2015. available at at https://agrariansciences. blogspot.ru/2015/06/nazareno-strampelli-e-il-suo-tempo_18.html.

Marone D., Del Olmo A.I., Laidò G., Sillero J.C., Emeran A.A., Russo M.A., Ferragonio P., Giovanniello V., Mazzucotelli E., De Leonardis A.M., de Vita P., Blanco A., Cattivelli L., Rubiales D., Mastrangelo A.M. Genetic analysis of durable 
resistance against leaf rust in durum wheat. Mol. Breed. 2009;24(1):25-39. DOI: 10.1007/s11032-009-9268-9.

Masoni A. Grain Quality of Durum Wheat as Affected by Environment and Cropping Practices. Research Project. Programmi di Ricerca Scientifica di Rilevante Interesse Nazionale Cofinanziamento 1999. Was available at http:// www.agr.unipi.it/daga/ MURST.

Moscetti I., Tundo S., Janni M., Sella L., Gazzetti K., Tauzin A., Giardina T., Masci S., Favaron F., D'Ovidio R. Constitutive expression of the xylanase inhibitor TAXI-III delays Fusarium head blight symptoms in durum wheat transgenic plants. Mol. Plant-Microbe Inter. 2013; 26(12):1464-1472. DOI: 10.1094/MPMI-04-13-0121-R.

Novaro P., D'Egidio M.G., Mariani B.M., Nardi S. Combined effect of protein content and hightemperature drying system on pasta cooking quality. Cereal Chem. 1993;70:716-719.

OEC - Economic Complexity Ranking of Countries (2013-2017). available at https://atlas.media. mit.edu/it.

Para R. L'agricoltura di fronte alle sfide della sicurezza alimentare, dei cambiamenti climatici e della sostenibilità: la lezione del genetista Nazareno Strampelli. Presentazione 21 maggio 2016, Macerata, I'Istituto Agrario "Giuseppe Garibaldi". available at http://www.accademiageorgica.it/ eventi/2016/ buoncompleannostrampelli.html.

Pasqualone A. Italian durum wheat breads. In book: Bread consumption and health, Chapter: Italian durum wheat breads, Publisher: Nova Science Publisher Inc., Eds: M.T. Pedrosa, S. Clerici. 2012;57-79.

Pogna N. Il miglioramento genetico dei frumenti e l'eredità di Nazareno Strampelli. Presentazione 21 maggio 2016, Macerata, I'Istituto Agrario "Giuseppe Garibaldi". available at http://www.accademiageorgica.it/eventi/2016/ buoncompleannostrampelli.html.

Pogna N.E., Autran J.C., Mellini F., Laiandra D., Feillet P. Chromosome 1B-encoded gliadins and glutenins subunits in durum wheat: genetic and relationship to gluten strength. J. Cereal Sci. 1990;11:15-34.

Pogna N.E., Gazza L., Corona V., Zanin R., Niglio A., Mie E., Palumbo M., Boggini G. Puroindolines and kernel hardness in wheat species. In: Ng P.K.W., Wrigley C.W. (eds). Wheat quality elucidation: the Bushuk legacy. AACC, St. Paul, MN, USA. 2002;155-169.

Pogna N.E., Tusa P., Boggini G. Genetics and biochemical aspects of dough quality in wheat. Adv. Food. Sci. 1996;18:145-151.

Porfiri O. I frumenti di Strampelli ad oltre un secolo dalla loro costituzione. Presentazione 21 maggio 2016, Macerata, I'Istituto Agrario "Giuseppe Garibaldi". available at http://www.accademiageorgica.it/eventi/2016/ buoncompleannostrampelli.html

Porceddu E., Blanco A. Evolution of durum wheat breeding in Italy: Porceddu E., Damania A.B., Qualset C.O. (eds). Proceedings of the International Symposium on Genetics and breeding of durum wheat Bari: CIHEAM. 2014;157-173 (Options Méditerranéennes: Série A. Séminaires Méditerranéens; $n$. 110).

Porceddu E., Laiandra D., Scarascia Mugnozza G.T. Genetics of seed proteins in wheat. Proceedings of Seed Proteins, Nijhoff and Junk Publication, London. 1983;77-141.

Rampino P., Mita G., Fasano P., Borrelli G.M., Aprile A., Dalessandro G., De Bellis L., Perrotta C. Novel durum wheat genes up-regulated in response to a combination of heat and drought stress. Plant Physiol. Biochem. 2012;56:7278. DOI: 10.1016/j.plaphy.2012.04.006.

Salvi S. Sulle tracce di Nazareno Strampelli. Treia, Accademia Georgica. 2013;70.

Salvi S. L'uomo che voleva nutrire il mondo: i primi 150 anni di Nazareno Strampelli. Treia, Accademia Georgica. 2016a;1-95.

Salvi S. Povero Nazareno Strampelli, “prigioniero” del grano Cappelli...!, agosto 2016b. Agrarian Sciences. available at.

Salvi S., Porfiri O., Ceccarelli S. Nazareno Strampelli, the 'Prophet' of the green revolution. 2013. J. Agric. Sci. 151, 1-5. DOI: 10.1017/S0021859612000214.

Salvi S., Tuberosa R. To clone or not to clone plant QTLs: present and future challenges. Trends Plant Sci. 2005;10:297-304. DOI: 10.1016/j. tplants.2005.04.008.
Scarascia Mugnozza G.T. The contribution of Italian wheat geneticists: From Nazareno Strampelli to Francesco D'Amato: Tuberosa R., Phillips R.L., Gale M. (eds). Proceedings of the International Congress "In the Wake of the Double Helix: from the Green Revolution to the Gene Revolution". Bologna, 27-31 May 2003, Italy. 2005;53-75.

Scarascia Mugnozza G.T., D'Amato F., Avanzi S., Bagnara D., Belli M.L., Bozzini A., Brunori A., Cervigni T., Devreux M., Donini B., Giorgi B., Martini G., Monti L.M., Moschini E., Mosconi C., Porreca G., Rossi L. Mutation breeding for durum wheat (Triticum turgidum ssp. durum Desf.) improvement in Italy. Mutat. Breed. Rev. 1993;10:1-28.

Sehgal D., Yadav R. Molecular Markers Based Approaches for Drought Tolerance: Jain S., Brar D. (eds). Mol. Tech. Crop Improv. Springer, Dordrecht. 2010. DOl https://doi.org/10.1007/978-90-481-2967-6_9.

Simeone R., Galasso I., Pignone D., Blanco A. Introgression of powdery mildery resistance from wild species to wheat. Proceedings of the 11th EWAC Conference. Novosibirsk, Russia, July 24-28, 2000; 55-59.

Spano G., Di Fonzo N., Perrotta C., Platani C., Ronga G., Lawlor D.W., Napier J.A., Shewry P.R. Physiological characterization of "stay green" mutants in durum wheat. J. Exp. Bot. 2003;54(386):1415-1420. DOI: 10.1093/jxb/erg150 .

Strampelli N. Origini, sviluppi, lavori e risultati. Milano, Italy: Istituto Nazionale di Genetica per la Cerealicoltura, Alfieri \& Lacroix. 1932.

Tardieu F. Virtual plants: modelling as a tool for the genomics of tolerance to water deficit. Trends Plant Sci. 2003;8:9-14. DOI: 10.1016/S13601385(02)00008-0.

Terzi V., Pastori G., Shewry P.R., Di Fonzo N., Stanca M., Faccioli P. Real-time PCRassisted selection of wheat plants transformed with HMW glutenin subunit genes. J. Cereal Sci. 2005;41 (1):133-136. DOI:10.1016/j.jcs.2004.08.001

Tuberosa R., Giuliani S., Parry M.A.J., Araus J.L. Improving water use efficiency in Mediterranean agriculture: what limits the adoption of new technologies? Ann. Appl. Biol. 2007;150:157-162. DOI: 10.1111/j.1744-7348.2007.0012.

Tuberosa R., Salvi S. Genomics-based approaches to improve drought tolerance of crops. Trends Plant Sci. 2006;11:405-412. DOI: 10.1016/j. tplants.2006.06.003.

Tuberosa R., Salvi S., Sanguineti M.C., Landi P., Maccaferri M., Conti S. Mapping QTLs regulating morpho-physiological traits and yield: Case studies, shortcomings and perspectives in drought-stressed maize. Ann. Bot. 2002;89:941-963. https://doi.org/10.1093/aob/mcf134.

Vallega V., Rubies-Autonell C., Pisi A.M., Ratti C. Indexed data for comparing the reaction to cereal soilborne mosaic virus of durum wheat cultivars assayed in different seasons. Ann. Wheat News. 2009;55:100-105.

Venora G., Blangiforti S. I grani antichi siciliani - Manuale tecnico per il riconoscimento delle varietà locali dei frumenti siciliani. Le Fate Editore, di Ragusa. 2017;1-196. ISBN-13: 978-88-940976-6-5.

Vallega J., Spagnoletti P.L., Porceddu E. Hystorical perspective of wheat breeding in Italy. Proceedings of the Fourth FAO/Rockefeller Foundation on Wheat Seminar, Tehran, Iran, May 21-June 2, 1973. FAO, Rome. 1974;115-125.

Vallega J., Zitelli G. New high yielding Italian durum wheat varieties: Scarascia Mugnozza G.T. (ed). Proceedings of the Symposium on Genetics and Breeding of durum wheat. Bari, Italy, May 14-18, 1973;373-399.

Wheat Initiative, 2019. available at https://www.wheatinitiative.org/

Wheat Initiative. The Expert Working Group on Durum Wheat Genomics and Breeding, 2019. available at https://www.wheatinitiative.org/durumwheat-genomics-and-breeding.

Zitelli G. Inheritance of resistant factors to some Italian races of Puccinia graminis tritici in several durum wheats (Wells, Lakota, Yuma, Alex 281, Alex 299). Proceedings of Cereal Rust Conference. Oeiras, Portugal. 1968;163-166.

Zitelli G. Genetic improvement of durum wheat for disease resistance: Scarascia Mugnozza G.T. (ed). Proceedings of Symp. Genet. Breed. Durum Wheat, Bari, May 14-18. University Bari, Bari, Italy. 1973;473-487.

Zitelli G., Vallega J. Ereditarietà dei caratteri di resistenza all'Erysiphe graminis triticie alla Puccinia graminis tritici presenti in Yuma (T. durum). Genetica Agraria, 1968;22:207-222.

Конфликт интересов. Автор заявляет об отсутствии конфликта интересов.

Для цитирования. Ляпунова О.А. Селекция твердой пшеницы в Италии. Письма в Вавиловский журнал генетики и селекции. 2019;5(1):19-34. DOI 10.18699/Letters2019-5-3.

For citation. Lyapunova Olga A. Durum wheat breeding in Italy. Pisma v Vavilovskii Zhurnal Genetiki $i$ Selektsii = Letters to Vavilov Journal of Genetics and Breeding. 2019;5(1):19-34. DOI 10.18699/Letters2019-5-3. (in Russian)

Поступила в редакцию 14.10.2019. После доработки 29.10.2019. Принята к публикации 29.10.2019. 